\title{
Effectiveness evaluation of temporary emission control action in 2016 in winter in Shijiazhuang, China
}

\author{
Baoshuang Liu ${ }^{1}$, Yuan Cheng ${ }^{1}$, Ming Zhou ${ }^{1}$, Danni Liang ${ }^{1}$, Qili Dai ${ }^{1}$, Lu Wang ${ }^{1}$, Wei Jin ${ }^{2}$, Lingzhi Zhang ${ }^{2}$, \\ Yibin Ren ${ }^{2}$, Jingbo Zhou ${ }^{2}$, Chunling Dai ${ }^{2}$, Jiao Xu ${ }^{1}$, Jiao Wang ${ }^{1}$, Yinchang Feng ${ }^{1}$, and Yufen Zhang ${ }^{1}$ \\ ${ }^{1}$ State Environmental Protection Key Laboratory of Urban Ambient Air Particulate Matter Pollution Prevention and Control, \\ College of Environmental Science and Engineering, Nankai University, Tianjin, 300350, China \\ ${ }^{2}$ Shijiazhuang Environmental Monitoring Center of Hebei Province, Shijiazhuang, Hebei, 050022, China
}

Correspondence: Yinchang Feng (fengyc@nankai.edu.cn) and Yufen Zhang (zhafox@126.com)

Received: 27 October 2017 - Discussion started: 18 December 2017

Revised: 22 March 2018 - Accepted: 10 April 2018 - Published: 23 May 2018

\begin{abstract}
To evaluate the environmental effectiveness of the control measures for atmospheric pollution in Shijiazhuang, China, a large-scale controlling experiment for emission sources of atmospheric pollutants (i.e. a temporary emission control action, TECA) was designed and implemented during 1 November 2016 to 9 January 2017. Compared to the no-control action and heating period (NCAHP), under unfavourable meteorological conditions, the mean concentrations of $\mathrm{PM}_{2.5}, \mathrm{PM}_{10}, \mathrm{SO}_{2}, \mathrm{NO}_{2}$, and chemical species ( $\mathrm{Si}$, $\mathrm{Al}, \mathrm{Ca}^{2+}, \mathrm{Mg}^{2+}$ ) in $\mathrm{PM}_{2.5}$ during the control action and heating period (CAHP) still decreased by 8, 8, 5, 19, 30.3, $4.5,47.0$, and $45.2 \%$, respectively, indicating that the control measures for atmospheric pollution were effective. The effects of control measures in suburbs were better than those in urban area, especially for the control effects of particulate matter sources. The control effects for emission sources of carbon monoxide (CO) were not apparent during the TECA period, especially in suburbs, likely due to the increasing usage of domestic coal in suburbs along with the temperature decreasing.

The results of positive matrix factorization (PMF) analysis showed that crustal dust, secondary sources, vehicle emissions, coal combustion and industrial emissions were main $\mathrm{PM}_{2.5}$ sources. Compared to the whole year (WY) and the no-control action and no-heating period (NCANHP), the contribution concentrations and proportions of coal combustion to $\mathrm{PM}_{2.5}$ increased significantly during other stages of the TECA period. The contribution concentrations and proportions of crustal dust and vehicle emissions to $\mathrm{PM}_{2.5}$ decreased noticeably during the CAHP compared to other
\end{abstract}

stages of the TECA period. The contribution concentrations and proportions of industrial emissions to $\mathrm{PM}_{2.5}$ during the CAHP decreased noticeably compared to the NCAHP. The pollutants' emission sources during the CAHP were in effective control, especially for crustal dust and vehicles. However, the necessary coal heating for the cold winter and the unfavourable meteorological conditions had an offset effect on the control measures for emission sources to some degree. The results also illustrated that the discharge of pollutants might still be enormous even under such strict control measures.

The backward trajectory and potential source contribution function (PSCF) analysis in the light of atmospheric pollutants suggested that the potential source areas mainly involved the surrounding regions of Shijiazhuang, i.e. south of Hebei and north of Henan and Shanxi. The regional nature of the atmospheric pollution in the North China Plain revealed that there is an urgent need for making cross-boundary control policies in addition to local control measures given the high background level of pollutants.

The TECA is an important practical exercise but it cannot be advocated for as the normalized control measures for atmospheric pollution in China. The direct cause of atmospheric pollution in China is the emission of pollutants exceeding the air environment's self-purification capacity, which is caused by an unreasonable and unhealthy pattern for economic development in China. 


\section{Introduction}

As a consequence of rapid industrialization and urbanization, China has been suffering from air quality degradation in recent years (Zhao et al., 2011; Fu et al., 2014; Han et al., 2014; Gao et al., 2015; Hao et al., 2017). Frequently occurring severe haze is characterized by long duration, extensive coverage, and sharply increasing particulate concentration (Tao et al., 2014; X. Y. Zhang et al., 2015; G. Wang et al., 2016; Jiang and Xia, 2017). It has been suggested that severe haze pollution increases the risk of respiratory and cardiovascular diseases (Chen et al., 2013; Pan et al., 2014; Z. L. Zhang et al., 2014; Gao et al., 2015; Zhou et al., 2015). On the basis of previous statistics, there are four haze-prone city clusters in China, including the Beijing-Tianjin-Hebei region, Yangtze River Delta, Pearl River Delta, and Sichuan Basin (Wu et al., 2008; Tao et al., 2013a; Bi et al., 2014; Fu et al., 2014; Q. Z. Wang et al., 2015; L. Zhang et al., 2015; X. Chen et al., 2016; H. M. Li et al., 2016; Fu and Chen, 2017). In recent years, the role of particulates in hazy events has been becoming more and more prominent. The particulates can be discharged from a variety of sources or formed by physicochemical or aqueous-oxidation reactions among gaseous precursors, which have significant negative effects on climate, atmospheric visibility, and public health (Quinn and Bates, 2003; Tai et al., 2010; Zhang et al., 2010; Chen et al., 2015; Lee et al., 2015; Shen et al., 2015; Fu and Chen, 2017). The high observed concentrations of fine particles and prolonged haze events have occurred frequently during autumn and winter and covered large regions in China. In some cases, the instantaneous mass concentration of $\mathrm{PM}_{2.5}$ had reached up to $1000 \mu \mathrm{g} \mathrm{m}^{-3}$ (J. K. Zhang et al., 2014; Qin et al., 2016), which caused extensive concern from citizens and government agencies.

Confronted with severe air pollution and degradation of air quality, the government has implemented a variety of control measures in recent years, including the odd-and-even license plate rule (http://www.sjz.gov.cn/col/1496488850551/2016/ 11/17/1502101082513.html, last access: 5 August 2017), the mandatory installation of desulfurization, denitration, and other pollution-controlling facilities in factories (Ma et al., 2015; Liu et al., 2017a; Peng et al., 2017), and the on-line monitoring system structure plan on construction sites, for example. The atmospheric quality in China has been notably improved so far. From 2013 to 2016, the concentrations of atmospheric pollutants in China showed a decreasing trend, and the annual mean concentrations of $\mathrm{PM}_{2.5}$, $\mathrm{PM}_{10}, \mathrm{SO}_{2}$, and $\mathrm{NO}_{2}$ in 2016 reached up to $50,85,21$, and $39 \mathrm{\mu g} \mathrm{m}^{-3}$, respectively, and significantly lower than those in 2013 (http://www.zhb.gov.cn/hjzl/zghjzkgb/lnzghjzkgb/, last access: 5 August 2017). However, the annual mean concentrations of $\mathrm{PM}_{2.5}$ and $\mathrm{PM}_{10}$ in 2016 were still 1.4 and 1.2 times higher than the National Ambient Air Quality Standards (NAAQS) (GB3095-2012 guideline value (annual) of Grade II, $\mathrm{PM}_{2.5}: 35 \mu \mathrm{g} \mathrm{m}^{-3} ; \mathrm{PM}_{10}: 70 \mu \mathrm{g} \mathrm{m}^{-3}$ ). Note that the concentrations of $\mathrm{PM}_{2.5}$ and $\mathrm{PM}_{10}$ in the Beijing-TianjinHebei region were up to 71 and $119 \mu \mathrm{g} \mathrm{m}^{-3}$ in 2016 and 2.0 and 1.7 times higher than the NAAQS (GB3095-2012 guideline value (annual) of Grade II), respectively. Therefore, China still has a lot of work to do to improve the national air quality.

Over the last decade, the Chinese government has implemented stricter control measures for emission sources during multiple international events held in China than normal times (T. Wang et al., 2010; Guo et al., 2013; Liu et al., 2013; P. L. Chen et al., 2016; Sun et al., 2016; Wang et al., 2017). For instance, the first attempt took place during the Beijing 2008 Olympic Games (Guo et al., 2013). Drastic control actions were executed to cut down the emissions of atmospheric pollutants from motor vehicles, industries, and building construction activities (UNEP, 2009; M. Wang et al., 2009; T. Wang et al., 2010). UNEP (2009) suggested that the concentration of $\mathrm{PM}_{10}$ in Beijing was reduced by $20 \%$ due to the emission reduction measures. Liu et al. (2013) reported that the concentrations of $\mathrm{SO}_{2}$, $\mathrm{NO}_{2}, \mathrm{PM}_{10}$, and $\mathrm{PM}_{2.5}$ were reduced by $66.8,51.3,21.5$, and $17.1 \%$, respectively, during the 2010 Asian Games in Guangzhou, China, and during which stricter control measures for emission sources were implemented. Furthermore, further stricter controls for emission sources were implemented in both Beijing and its surrounding regions during the 2014 Asia-Pacific Economic Cooperation (APEC) summit and parade. Compared to no control during APEC and parade, a decreasing trend with 51.6-65.1 and 34.2-64.7\% of $\mathrm{PM}_{2.5}$ concentrations during the control period was reported (Wang et al., 2017). Eventually, all the efforts led to blue-sky days during the APEC, which was acknowledged as "APEC Blue" (H. B. Wang et al., 2016). As we can see, the air quality can be improved in response to stricter emission controls for international events held in China. However, once these stricter control measures were repealed and the air quality subsequently deteriorated (http://www.mep.gov. $\mathrm{cn} / \mathrm{gkml} / \mathrm{hbb} / \mathrm{qt} / 201412 / \mathrm{t} 20141218 \_293152$.htm, last access: 7 August 2017), it was clear that the prevention and control of air pollution in China still had a long way to go.

Shijiazhuang $\left(38.05^{\circ} \mathrm{N}, 114.58^{\circ} \mathrm{E}\right)$, a hinterland city of the North China Plain with a high population density, is an important city in the Beijing-Tianjin-Hebei region (Sun et al., 2013). The rapid industry development has a great contribution to this city's economic growth and degradation of air quality at the same time (Du et al., 2010; Li et al., 2015; Yang et al., 2015; L. L. Yang et al., 2016). Shijiazhuang has been one of the cities with the most serious air pollution in the world (https://www.statista.com/chart/ 4887/the-20-worst-cities-worldwide-for-air-pollution/,

last access: 9 August 2017), and deteriorating air quality poses a great risk to public health (http://www.who.int/en/news-room/fact-sheets/detail/ ambient-(outdoor)-air-quality-and-health, last access: 9 August 2017), as well as the expansion of the economy. 


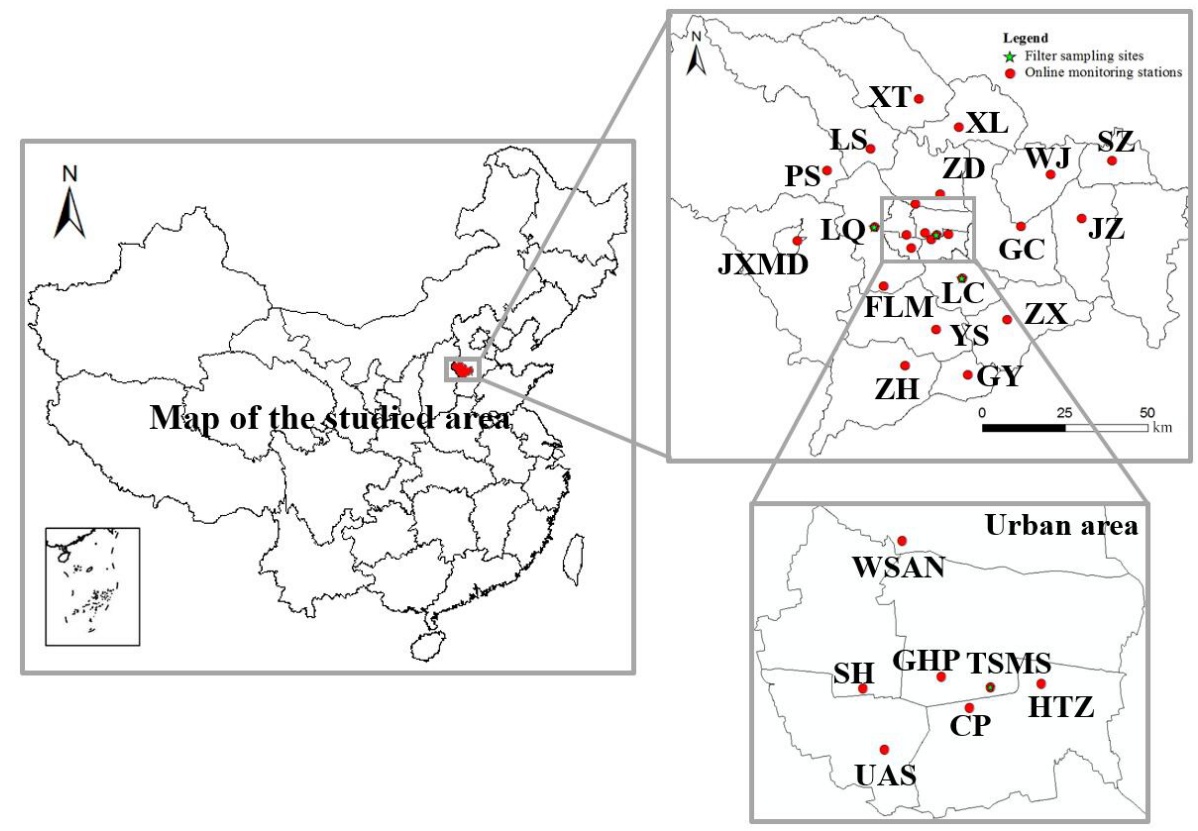

Figure 1. Map of the online monitoring stations and the filter membrane sampling sites in Shijiazhuang. The 24 online monitoring stations mainly include the 22nd middle school (TSMS), Fenglong Mountain (FLM), high-tech zone (HTZ), Great Hall of the People (GHP), Century Park (CP), water source area in the northwest (WSAN), university area in the southwest (UAS), staff hospital (SH), Gaoyi (GY), Gaocheng (GC), Xingtang (XT), Jinzhou (JZ), Jingxing mining district (JXMD), Lingshou (LS), Luquan (LQ), Luancheng (LC), Pingshan (PS), Shenze (SZ), Wuji (WJ), Xinle (XL), Yuanshi (YS), Zanhuang (ZH), Zhaoxian (ZX), and Zhengding (ZD). The filter membrane sampling sites are mainly located in TSMS, LQ, and LC.

The government of Shijiazhuang has adopted a variety of control measures (http://www.sjzhb.gov.cn/, last access: 9 August 2017); however, it seems that there is no improvement in air quality of Shijiazhuang so far, and the atmospheric pollution is still heavy. In 2016, the annual concentrations of $\mathrm{PM}_{2.5}$ and $\mathrm{PM}_{10}$ in Shijiazhuang reached up to 70 and $123 \mu \mathrm{g} \mathrm{m}^{-3}$, respectively, which were 2.0 and 1.8 times higher than the NAAQS (GB3095-2012 Grade II) (http://kjs.mep.gov.cn/hjbhbz/bzwb/dqhjbh/dqhjzlbz/, last access: 10 August 2017). Especially in the heating period in winter, the degree of atmospheric pollution in Shijiazhuang was even more serious. The effectiveness of control measures has been queried in recent years. Therefore, based on previous examples of APEC, parade and the Asian Games, etc., a large-scale controlling experiment for atmospheric pollutant sources (i.e. TECA) was designed and implemented to investigate whether control measures in Shijiazhuang were effective for the atmospheric pollution. The experiment was carried out in Shijiazhuang from 1 November 2016 to 9 January 2017, during which more stringent control measures of atmospheric pollution than usual were put into practice. Then, by combining the changes of atmospheric pollutants concentrations, emission source contributions, and other factors such as meteorological conditions, regional transmission, etc., the effectiveness of control measures was evaluated before and after the control measures were taken.

\section{Materials and methods}

\subsection{Site description}

Shijiazhuang City is located in the east of the Taihang Mountains in the north of China (Fig. 1), and the urban area is $15848 \mathrm{~km}^{2}$, with a population of more than 10 million in 2016. Shijiazhuang is a large industrial city that is famous for raw materials, energy production, and the steel, power, and cement industries. The number of vehicles was more than 2.0 million until 2016. Shijiazhuang has a typical temperate and monsoonal climate with four clearly distinct seasons, with northeasterly, southeasterly, and northwesterly winds prevailing during the TECA period (Fig. S1 in the Supplement). The mean wind speed was $0.6 \mathrm{~m} \mathrm{~s}^{-1}$, and the average temperature was $4.9^{\circ} \mathrm{C}$ during the TECA period. The mean relative humidity was up to $76.5 \%$, and the mean height of the mixed layer was $509 \mathrm{~m}$ during the TECA period. The meteorological conditions during the four stages of the TECA period in Shijiazhuang were shown in Table 1.

The seven monitoring sites including the 22nd middle school (TSMS), high-tech zone (HTZ), Great Hall of the People (GHP), Century Park (CP), water source area in the northwest (WSAN), university area in the southwest (UAS), 
Table 1. The meteorological conditions during the four stages (NCANHP, NCAHP, CAHP, and ACA) of the TECA period in Shijiazhuang.

\begin{tabular}{|c|c|c|c|c|c|c|c|c|}
\hline & \multicolumn{2}{|c|}{ NCANHP $^{\mathrm{c}}$} & \multicolumn{2}{|c|}{ NCAHP $^{d}$} & \multicolumn{2}{|c|}{ CAHP $^{\mathrm{e}}$} & \multicolumn{2}{|c|}{$\mathrm{ACA}^{\mathrm{f}}$} \\
\hline & Ave. $^{\mathrm{a}}$ & $\mathrm{SD}^{\mathrm{b}}$ & Ave. & SD & Ave. & SD & Ave. & SD \\
\hline Temperature $\left({ }^{\circ} \mathrm{C}\right)$ & 8.4 & 3.6 & 7.4 & 2.4 & 3.1 & 3.8 & 0.7 & 2.7 \\
\hline Relative humidity (\%) & 77.7 & 17.0 & 73.4 & 15.7 & 71.5 & 18.0 & 83.3 & 18.1 \\
\hline Wind speed $\left(\mathrm{m} \mathrm{s}^{-1}\right)$ & 0.7 & 1.2 & 0.6 & 0.6 & 0.4 & 1.0 & 0.5 & 1.1 \\
\hline Height of mixed layer (m) & 540 & 144 & 590 & 274 & 474 & 299 & 431 & 360 \\
\hline
\end{tabular}

${ }^{a}$ Ave. represents average value. ${ }^{b}$ SD represents standard deviation. ${ }^{c}$ NCANHP represents the no-control action and no-heating period. ${ }^{\mathrm{d}}$ NCAHP represents the no-control action and heating period. ${ }^{\mathrm{e}}$ CAHP represents the control action and heating period. ${ }^{\mathrm{I}}$ ACA represents after control action.

and staff hospital (SH) are located in urban area of Shijiazhuang. The other 17 sites including Fenglong Mountain (FLM), Gaoyi (GY), Gaocheng (GC), Xingtang (XT), Jinzhou (JZ), Jingxing mining district (JXMD), Lingshou (LS), Luquan (LQ), Luancheng (LC), Pingshan (PS), Shenze (SZ), Wuji (WJ), Xinle (XL), Yuanshi (YS), Zanhuang (ZH), Zhaoxian (ZX), and Zhengding (ZD) are situated in suburbs of Shijiazhuang. More details are shown in Table S1 in the Supplement.

\subsection{Sampling and analysis}

\subsubsection{Sampling}

From 1 November 2016 to 9 January 2017, the concentrations of $\mathrm{PM}_{2.5}, \mathrm{PM}_{10}, \mathrm{SO}_{2}, \mathrm{NO}_{2}, \mathrm{CO}$, and $\mathrm{O}_{3}$ and synchronous meteorological conditions (temperature, relative humidity, wind speed, and wind direction) were monitored in the 24 online monitoring sites belonging to national, provincial, and city controlling points (Fig. 1). More details about monitoring instruments are described in Table S2. The heights of the mixed layer were measured with a lidar scanner (AGHJ-I-LIDAR; HPL), which was set at an atmospheric gradient monitoring station in Shijiazhuang near the CP site (Fig. 1), and more details are shown in the Supplement. The $\mathrm{PM}_{2.5}$ filter membrane samples were collected at the TSMS, LQ, and LC sites from 24 November 2015 to 9 January 2017. Three sampling sites were set on the rooftops of buildings at $12-15 \mathrm{~m}$ above ground level. Meanwhile, the parallel samples and the field blanks were also collected at each site. More details about filter membrane sampling are shown in Table S3. Before sampling, the quartz filter membranes ( $47 \mathrm{~mm}$ in diameter, Whatman, England) and polypropylene filter membranes $(47 \mathrm{~mm}$ in diameter, Beijing Synthetic Fiber Research Institute, China) were baked in the oven at 500 and $60^{\circ} \mathrm{C}$, respectively. All the filter membranes after sampling were stored at $4{ }^{\circ} \mathrm{C}$ before subsequent gravimetric and chemical analysis to improve the accuracy of experimental results.

\subsubsection{Gravimetric and chemical analysis}

A $24 \mathrm{~h}$ equilibrium process of $\mathrm{PM}_{2.5}$ filter membranes was performed at a condition of constant temperature $\left(20 \pm 1^{\circ} \mathrm{C}\right)$ and humidity (45-55\%) before gravimetric analysis. For the gravimetric analysis, all the filter membranes were weighted twice on a microbalance with a resolution of $0.01 \mathrm{mg}$ (Mettler Toledo, XS105DU) before and after sampling. An electrostatic eliminating device was applied to ensure the accuracy of gravimetric results.

After the gravimetric analysis, the quartz filter membranes which carried atmospheric particulates were used to analyse water-soluble ions by ion chromatography (Thermo Fisher Scientific, Dionex, ICS-5000+). One-eighth of the filter membrane was cut up and put into a $25 \mathrm{~mL}$ glass tube with $20 \mathrm{~mL}$ ultrapure water. After $1 \mathrm{~h}$ of ultrasonic extraction and 3 min of centrifugalization, the supernatant was filtered with a disposable filter head $(0.22 \mu \mathrm{m})$ for subsequent instrumental analysis. The ions analysed included $\mathrm{SO}_{4}^{2-}, \mathrm{NO}_{3}^{-}, \mathrm{Cl}^{-}$, $\mathrm{NH}_{4}^{+}, \mathrm{K}^{+}, \mathrm{Ca}^{2+}, \mathrm{Na}^{+}$, and $\mathrm{Mg}^{2+}$, and more details were shown in Figs. S2 and S3. Prior to the ion detection, standard solutions were prepared and detected more than three times and low relative standard deviations (RSDs) were obtained. Analytical quantification was carried out by using calibration curves made from standard solutions prepared.

Polypropylene filter membranes were used for elemental analysis by inductively coupled plasma mass spectrometry (ICP-MS, Agilent 7700x). The perchloric acid-nitric acid digestion method was applied for the pretreatment of filter membranes. Aggregately, 10 elemental species (Al, Si, Ti, $\mathrm{Cr}, \mathrm{Mn}, \mathrm{Fe}, \mathrm{Cu}, \mathrm{Zn}, \mathrm{As}$, and $\mathrm{Pb}$ ) were determined. The detection limits of all the elements are shown in Table S4. For quality assurance and quality control (QA / QC), standard reference materials were pretreated and analysed with the same procedure, with the recovered values for all the target elements falling into the range of or within $5 \%$ of certified values.

The organic carbon (OC) and elemental carbon (EC) were determined on a $0.558 \mathrm{~cm}^{2}$ quartz filter membrane punch by Desert Research Institute (DRI) model 2001 thermaloptical carbon analyser with IMPROVE A thermal-optical 
reflectance (TOR) protocol. The quartz filter membrane was heated stepwise to temperatures of $140,280,480$, and $580^{\circ} \mathrm{C}$ in a non-oxidizing helium (He) oven to analyse $\mathrm{OC} 1, \mathrm{OC} 2$, $\mathrm{OC} 3$, and $\mathrm{OC} 4$, respectively. Then, the oven was added to an oxidizing atmosphere of $2 \%$ oxygen $\left(\mathrm{O}_{2}\right)$ and $98 \% \mathrm{He}$, and the quartz filter membrane was gradually heated to 580, 740, and $840^{\circ} \mathrm{C}$ to analyse $\mathrm{EC} 1, \mathrm{EC} 2$, and EC3, respectively. The POC is defined as the carbon combusted after the initial introduction of oxygen and before the laser reflectance signal achieves its original value and the POC is specified as the fraction of OC. According to the IMPROVE A protocol, OC is defined as $\mathrm{OC} 1+\mathrm{OC} 2+\mathrm{OC} 3+\mathrm{OC} 4+\mathrm{POC}$, and $\mathrm{EC}$ is defined as EC1 + EC2 + EC3 - POC. For QA / QC, we carried out the measurement with the field blank filter membranes, standard sucrose solution, and repeated analysis in the study. During each season, the field blanks were sampled and the particulate samples have been corrected by the average concentration of the blanks. For checking the precision of the instrument, a replicate sample was analysed for every 10 samples, and the standard deviation $< \pm 5 \%$ was accepted. The method detection limits (MDLs) of OC and EC are 0.45 and $0.06 \mu \mathrm{g} \mathrm{cm}^{-2}$, respectively.

\subsection{PMF model}

The PMF model can decompose a matrix of sample data $(\mathbf{X})$ into two matrices: source profile $(\mathbf{F})$ and source contribution (G), in terms of observations at the sampling sites (Paatero and Tapper, 1994). The principle of PMF model can be described by

$\mathbf{X}_{i j}=\sum_{k=1}^{p} g_{i k} f_{k j}+e_{i j}$,

where $\mathbf{X}_{i j}$ represents the concentration of the $j$ th species in the $i$ th sample, $g_{i k}$ represents the contribution of the $k$ th source to the $i$ th sample, $f_{k j}$ represents the source profile of the $j$ th species from the $k$ th source, $e_{i j}$ represents the residual for the $j$ th species in the $i$ th sample, and $p$ represents the number of sources.

PMF can identify emission sources of $\mathrm{PM}_{2.5}$ without source profiles. Data below MDLs are retained for use in the PMF model with the related uncertainty adjusted in terms of the characteristic that the PMF model admits data to be signally weighed. To assess the stability of the solution, the object function $Q$ can be allowed to review the distribution of each species, which is expressed by

$Q=\sum_{i=1}^{n} \sum_{j=1}^{m}\left[\frac{x_{i j}-\sum_{k=1}^{p} g_{i k} f_{k j}}{\mu_{i j}}\right]^{2}$,

where $\mu_{i j}$ represents the uncertainty of the $j$ th species in the $i$ th sample, which is applied to weight the observations that include the sampling errors, missing data, detection limits, and outliers.

The purpose of the PMF model was to minimize the function (Eq. 2). Data below MDLs were retained and their uncertainties were set to 5/6 of the MDLs. Missing values were replaced by the median concentration of a given species, with an uncertainty of 4 times the median (Brown et al., 2015). For values that were larger than the MDLs, the calculation of uncertainty was in terms of a user-supplied fraction of the concentration and MDLs, and the error fraction was suggested as $10 \%$ by Paatero (2000). Uncertainty was described by

uncertainty $=$

$\sqrt{(\text { error fraction } \times \text { concentration })^{2}+(0.5 \times \mathrm{MDL})^{2}}$.

In this study, the EPA PMF 5.0 model was used to identify the $\mathrm{PM}_{2.5}$ sources in Shijiazhuang City based on the field investigation and change of $Q$ values, and finally five factors were chosen in PMF analysis. When five factors were chosen and input into PMF model, the calculated $Q$ value (5162) from the PMF model was close to theoretical values (5045). The observed $\mathrm{PM}_{2.5}$ concentrations and calculated $\mathrm{PM}_{2.5}$ concentrations from the PMF model showed high correlation ( $r=0.96$ ) (Fig. S4). $S / N$ is the signal-to-noise ratio, which is used to address weak and bad variables when running the PMF model (Paatero and Hopke, 2003). The signal vector is identified as $S$ and the noise vector is identified as $N$. Next, $S / N$ is defined as Eq. (4). Variables with $S / N \leq 0.2$ were removed from the analysis, while weak variables $(0.2 \leq S / N \leq 2.0)$ were down-weighted (Ancelet et al., 2012). $S / \bar{N}$ ratios of $\mathrm{As}, \mathrm{Ti}$, and $\mathrm{Cr}$ were lower than 1.0 in this study, and these species were set as weak variables.

$S / N=\sqrt{\sum s_{i}^{2} / \sum n_{i}^{2}}$,

where $i$ represents the chemical species in $\mathrm{PM}_{2.5}$.

\subsection{Backward trajectory and PSCF model}

In this study, the $72 \mathrm{~h}$ backward trajectory arriving in Shijiazhuang $\left(38.05^{\circ} \mathrm{N}, 114.58^{\circ} \mathrm{E}\right)$ was calculated at $1 \mathrm{~h}$ intervals during the CAHP by the Hybrid Single-Particle Lagrangian Integrated Trajectory (HYSPLIT) model. The final global analysis data were produced from the National Centers for Environmental Prediction's Global Data Assimilation System wind field reanalysis (https://ready.arl.noaa.gov/ archives.php, last access: 6 July 2017). The model was run four times per day at starting times, i.e. 00:00, 06:00, 12:00, 18:00 LT; the starting height was set at $100 \mathrm{~m}$ above the ground. The potential source contribution function (PSCF) model was used to identify the potential source areas in terms of the HYSPLIT analysis. The study region was divided into $i \times j$ small, equal grid cells. The trajectory clustering and PSCF model were performed by using the GIS-based software TrajStat (Y. Q. Wang et al., 2009; Liu et al., 2017a). 
The PSCF value was defined as

$\mathrm{PSCF}=\frac{m_{i j}}{n_{i j}}$,

where $i$ and $j$ were the latitude and longitude indices, $n_{i j}$ represented the number of endpoints that fell in the $i j$ cell, and $m_{i j}$ was the number of endpoints in the same cell that were related to the samples that were greater than the threshold criterion.

Based on the NAAQS (GB3095-2012 guideline value (24 h) of Grade II), the criterion values of $\mathrm{PM}_{2.5}, \mathrm{PM}_{10}, \mathrm{NO}_{2}$, and $\mathrm{CO}$ were set to $75,150,80 \mu \mathrm{g} \mathrm{m}^{-3}$, and $4 \mathrm{mg} \mathrm{m}^{-3}$, respectively. The criterion values of $\mathrm{SO}_{2}$ and $\mathrm{O}_{3}$ were set to 68 and $15 \mu \mathrm{g} \mathrm{m}^{-3}$ respectively, in terms of the average during the CAHP. When $n_{i j}$ is smaller than 3 times the grid average number of the trajectory endpoint $\left(n_{\text {ave }}\right)$, a weighting function $W\left(n_{i j}\right)$ was used to reduce uncertainty in cells (Dimitriou et al., 2015). The weighting function was defined by

$W P S C F_{i j}=\frac{m_{i j}}{n_{i j}} * W\left(n_{i j}\right)$

$W\left(\mathrm{n}_{i j}\right)=\begin{aligned} & 1.00,3 n_{\mathrm{ave}}<n_{i j} \\ & 0.70,1.5 n_{\mathrm{ave}}<n_{i j} \leq 3 n_{\mathrm{ave}} \\ & 0.40, n_{\mathrm{ave}}<n_{i j} \leq 1.5 n_{\mathrm{ave}} \\ & 0.20, n_{i j} \leq n_{\mathrm{ave}}\end{aligned}$

The studying field ranged from 33 to $51^{\circ} \mathrm{N}$, and 97 to $121^{\circ} \mathrm{E}$, and the region that was covered by the backward trajectories was divided into 432 grid cells of $1.0^{\circ} \times 1.0^{\circ}$. The total number of endpoints during the CAHP was 12672 . Accordingly, there was an average of 29 trajectory endpoints per cell $\left(n_{\text {ave }}=29\right)$.

\subsection{Measures taken in the controlling experiment}

The measures taken in the controlling experiment began on 18 November 2016 and ended on 31 December 2016 in Shijiazhuang (http://www.sjz.gov.cn/col/1490076478426/2016/ 11/17/1496988006188.html, last access: 11 July 2017). The measures taken in the control action were mainly aimed at controlling emission sources of atmospheric pollutants in Shijiazhuang, which mainly included five aspects: (1) reduce the usage of coal, (2) decrease industrial production, (3) inhibit dust emission, (4) restrict driving, and (5) prohibit open burning. More details are described in the Supplement.

A total of 1543 enterprises were shut down in the whole city of Shijiazhuang during the control action period, including pharmaceutical, steel, cement, coking, casting, glass, ceramics, calcium and magnesium, sheet, sand, and stone processing and other industries. Specific closed enterprises in different districts and counties are shown in Table S5. In closed enterprises in Shijiazhuang, the number of mining and stone processing enterprises was the largest, which was up to 733 and accounted for $48 \%$ of all the closed enterprises.
The number of casting and building materials enterprises was up to 297 and 227, respectively, accounting for 19 and $15 \%$ of all enterprises, respectively. In addition, 64 enterprises related to the pharmaceutical industry were halted only for the volatile organic compound (VOC) technology, and the 17 enterprises related to chemical industry were required to stop production. The number of closed enterprises for the cement and calcium-magnesium industries was up to 49 and 40 , respectively. The number of closed factories related to furniture and tanneries was 43, and the number of closed steel and coking enterprises was up to four and seven, respectively.

The average value of daily social electricity consumption from 18 November to 31 December 2016 was $103470000 \mathrm{~kW} \mathrm{~h}^{-1}$ (Fig. S5), which declined $10 \%$ compared to that of daily social electricity consumption from 1 to 17 November 2016, and declined $6 \%$ compared to that of daily social electricity consumption during the same period in 2015. Restriction of motor vehicles based on the oddand-even license plate rule in the urban area of Shijiazhuang resulted in the decrease in the average traffic flow on arterial roads, which was reduced about $30 \%$ compared to before the control action (Fig. S6). The dust emission can be reduced about $390 \mathrm{t}$ per day by a series of dust control measures. Compared to before the control action, the daily emissions of $\mathrm{SO}_{2}, \mathrm{NO}_{x}$, smoke dust, and VOCs reduced about 20, 33, 15 , and $7 \%$, respectively, during the control action period, on the basis of the statistics on pollutant emission inventories.

\section{Results and discussion}

\subsection{Variations in atmospheric pollutant concentrations}

\subsubsection{Temporal trend}

The time series of atmospheric pollutant concentrations during the TECA period are shown in Fig. 2. The average concentrations of $\mathrm{PM}_{2.5}$ and $\mathrm{PM}_{10}$ during the TECA period in Shijiazhuang were up to 181 and $295 \mu \mathrm{g} \mathrm{m}^{-3}$, respectively, which was 5.2 and 4.2 times the limit value (annual) of Grade II in the NAAQS. The ratio of $\mathrm{PM}_{2.5} / \mathrm{PM}_{10}$ reached up to 0.62 during the TECA period, indicating that fine particulate dominated the particulate pollution in Shijiazhuang. The mean concentration of $\mathrm{PM}_{2.5}$ during the TECA period was significantly higher than that during winter in Beijing $\left(95.50 \mu \mathrm{g} \mathrm{m}^{-3}\right)$, Tianjin $\left(144.6 \mu \mathrm{g} \mathrm{m}^{-3}\right)$, Hangzhou (127.9-144.9 $\left.\mu_{g^{-3}}{ }^{-3}\right)$, Heze $\left(123.6 \mu \mathrm{g} \mathrm{m}^{-3}\right)$, and Xinxiang $\left(111 \mathrm{\mu g} \mathrm{m}^{-3}\right)$ (Gu et al., 2011; Cheng et al., 2015; Liu et al., 2015; Feng et al., 2016; Liu et al., 2017a) and lower than those during winter in Handan $\left(240.6 \mu \mathrm{g} \mathrm{m}^{-3}\right)$ and Xi' an $\left(266.8 \mu \mathrm{g} \mathrm{m}^{-3}\right)$ (Meng et al., 2016; Zhang et al., 2011). Additionally, the NAAQS (GB30952012, Grade II) values of $\mathrm{SO}_{2}, \mathrm{NO}_{2}, \mathrm{O}_{3}$, and $\mathrm{CO}$ were $60,40,160 \mu \mathrm{g} \mathrm{m}^{-3}$, and $4 \mathrm{mg} \mathrm{m}^{-3}$, respectively. During the TECA period, the average concentration of $\mathrm{SO}_{2}\left(60 \mu \mathrm{g} \mathrm{m}^{-3}\right)$ could meet the NAAQS, and that of $\mathrm{NO}_{2}\left(81 \mu \mathrm{g} \mathrm{m}^{-3}\right)$ far ex- 


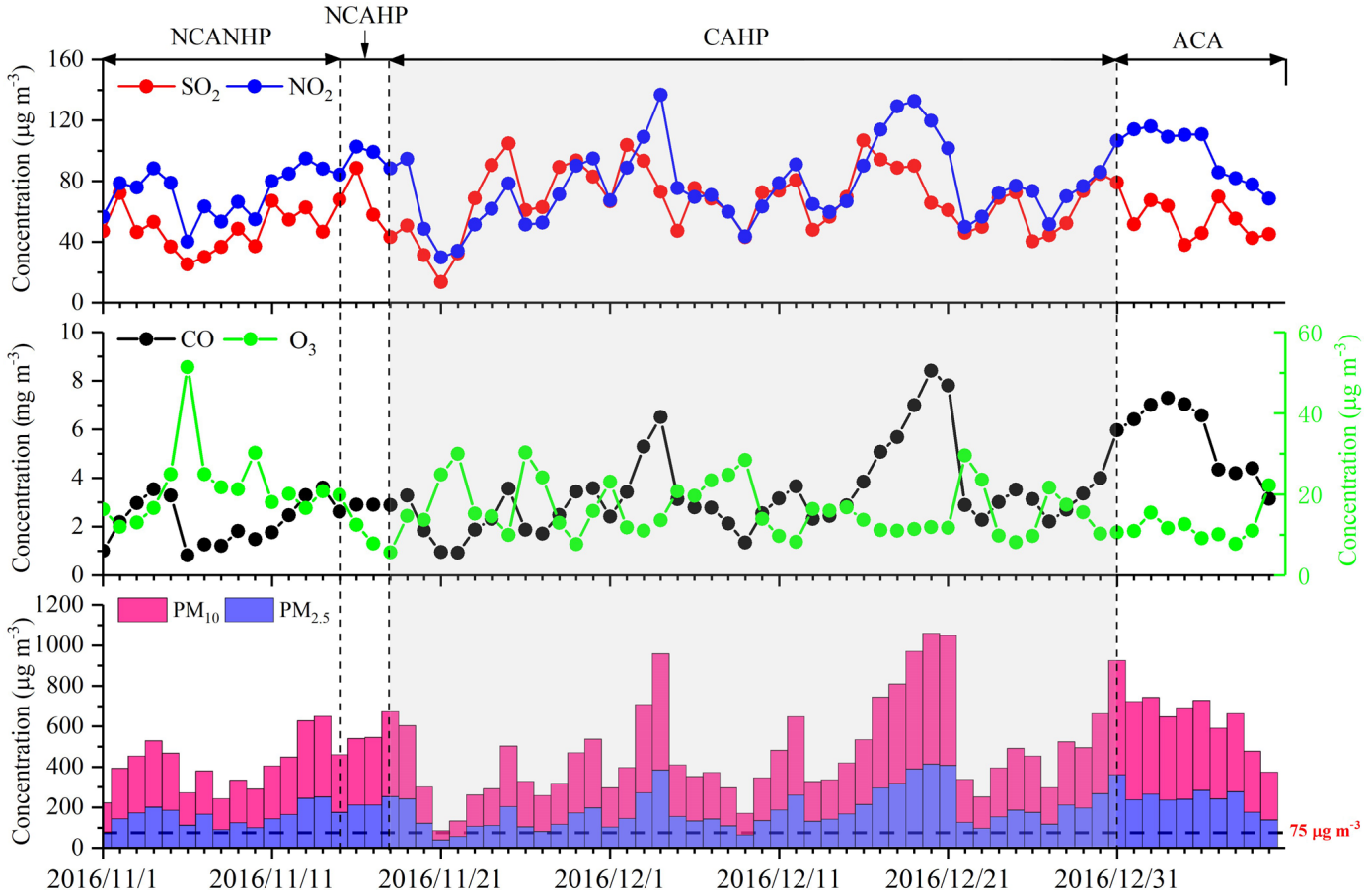

Figure 2. The variations in atmospheric pollutant concentrations during the four stages (NCANHP, NCAHP, CAHP, and ACA) of the TECA period in Shijiazhuang.

ceeded the NAAQS, while those of $\mathrm{CO}\left(3.4 \mathrm{mg} \mathrm{m}^{-3}\right)$ and $\mathrm{O}_{3}$ $\left(15 \mu \mathrm{g} \mathrm{m}^{-3}\right)$ were less than the NAAQS.

As is well known, coal-fired heating in Shijiazhuang began in 15 November 2016 (http://www.sjz.gov.cn/col/ 1497948647350/2016/11/16/1497954667980.html, last access 13 June 2017). Depending on the changes of atmospheric pollution sources and meteorological conditions (Table 1), the timeline of the TECA was divided into four stages: stage 1: no-control action and no-heating period (NCANHP), ranging from 1 to 14 November 2016; stage 2: no-control action and heating period (NCAHP), ranging from 15 to 17 November 2016; stage 3: control action and heating period (CAHP), ranging from 18 November to 31 December 2016; stage 4: after control action (ACA), ranging from 1 to 9 January 2017.

During the TECA period, the variations in atmospheric pollutant concentrations were mainly affected by the heating for winter and the control measures of the control action except for the meteorological conditions. Therefore, we defined the following equations to evaluate the effects of the heating and control action, respectively, based on the atmospheric pollutant concentrations during the different stages of TECA (i.e. NCANHP, NCAHP, CAHP, and ACA).

$P_{i-\text { heating }}=\frac{\left(C_{i-\mathrm{NCAHP}}-C_{i-\mathrm{NCANHP}}\right) \times 100}{C_{i-\mathrm{NCANHP}}}$
$P_{i-\text { action }}=\frac{\left(C_{i-\mathrm{NCAHP}}-C_{i-\mathrm{CAHP}}\right) \times 100}{C_{i-\mathrm{NCAHP}}}$

$P_{i-h e a t i n g}$ represents the increasing percentage $(\%)$ of atmospheric pollutant concentration because of the combined effects of heating for winter and meteorological conditions; $P_{i-\text { action }}$ represents the decreasing percentage $(\%)$ of atmospheric pollutant concentration because of the combined influences of control action and meteorological conditions; $C_{i-\mathrm{NCANHP}}$ represents the concentration $\left(\mu \mathrm{g} \mathrm{m}^{-3}, \mathrm{CO}\right.$ : $\mathrm{mg} \mathrm{m}^{-3}$ ) of atmospheric pollutant during the no-control action and no-heating period; $C_{i-\mathrm{NCAHP}}$ represents the concentration $\left(\mu \mathrm{g} \mathrm{m}^{-3}, \mathrm{CO}: \mathrm{mg} \mathrm{m}^{-3}\right)$ of atmospheric pollutant during the no-control action and heating period; $C_{i-\mathrm{CAHP}}$ represents the concentration $\left(\mu \mathrm{g} \mathrm{m}^{-3}, \mathrm{CO}: \mathrm{mg} \mathrm{m}^{-3}\right)$ of atmospheric pollutant during the control action and heating period.

During the NCANHP, the mean concentrations of $\mathrm{PM}_{2.5}$ and $\mathrm{PM}_{10}$ were 156 and $253 \mu \mathrm{g} \mathrm{m}^{-3}$ in Shijiazhuang, respectively. With the beginning of heating, the mean concentrations of $\mathrm{PM}_{2.5}$ and $\mathrm{PM}_{10}$ increased by 44 and $64 \mu \mathrm{g} \mathrm{m}^{-3}$

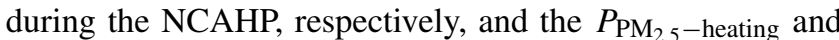

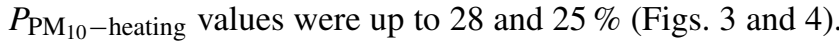
However, during the CAHP, the mean concentrations of $\mathrm{PM}_{2.5}$ and $\mathrm{PM}_{10}$ were 185 and $291 \mu \mathrm{g} \mathrm{m}^{-3}$, respectively, which decreased by 15 and $26 \mu \mathrm{g} \mathrm{m}^{-3}$ compared to the NC-

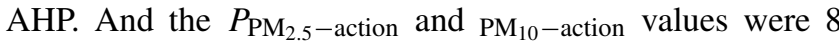
and $8 \%$, respectively. The mean height of the mixed layer 


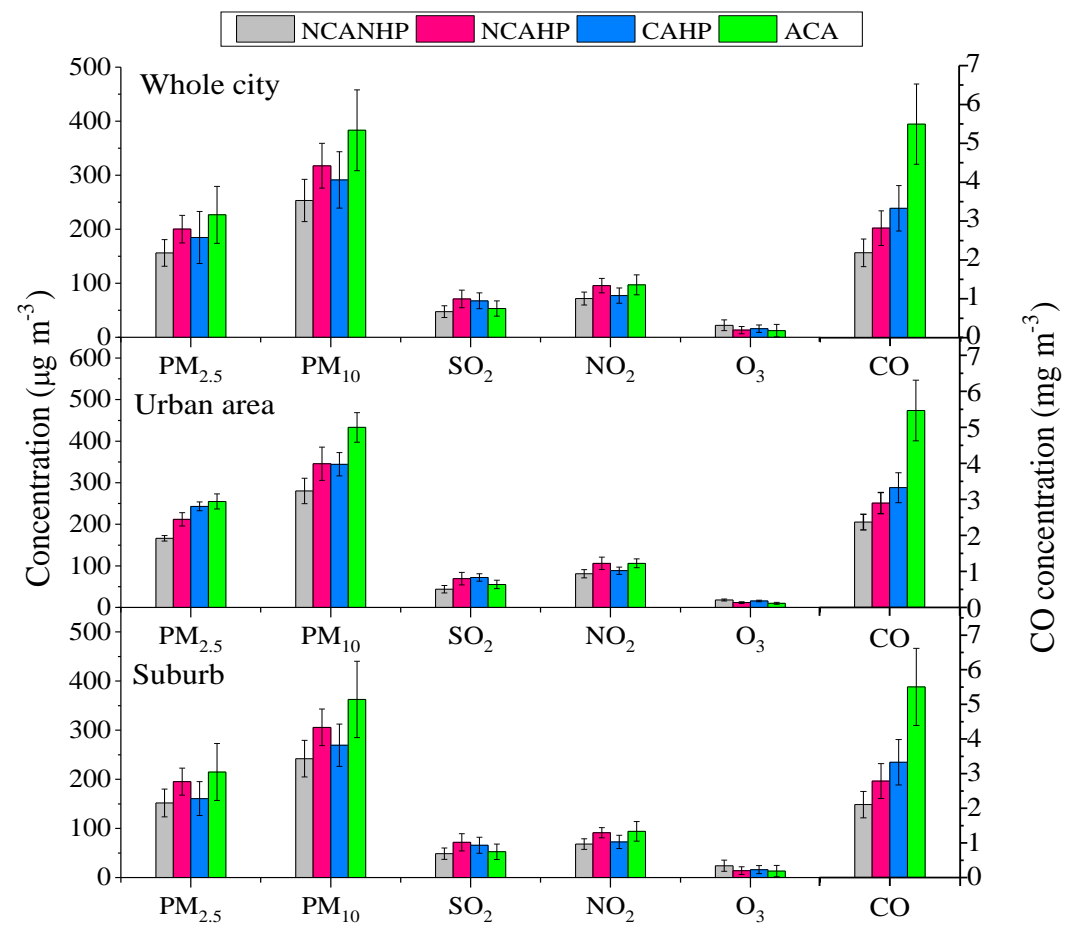

Figure 3. The concentration variations in $\mathrm{PM}_{2.5}, \mathrm{PM}_{10}$, and gaseous pollutants during the four stages (NCANHP, NCAHP, CAHP, and ACA) of the TECA period in Shijiazhuang. The error bar represents the standard deviation.

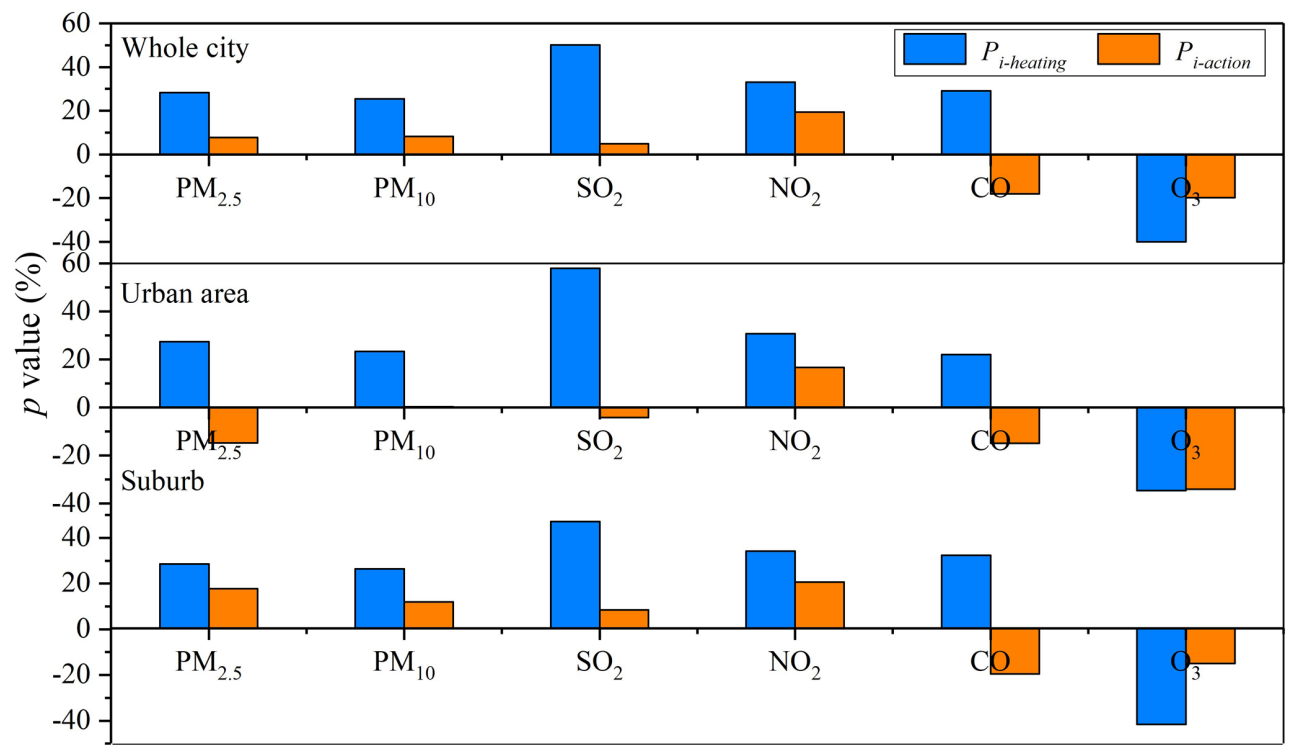

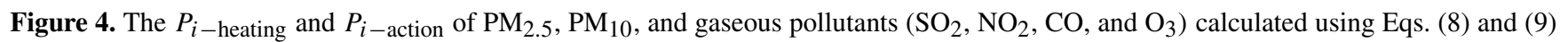
in an urban area and suburb in Shijiazhuang.

and the mean wind speed and temperature during the CAHP were lower than those during the NCAHP (Table 1). Unfavourable meteorological conditions during the CAHP had an offset effect on the control measures for emission sources. In view of Eq. (9), it can be seen that the positive values for $P_{\mathrm{PM}_{2.5}-\text { action }}$ and $P_{\mathrm{PM}_{10}}$-action are more able to show that control action was effective. During the ACA, the concentrations of $\mathrm{PM}_{2.5}$ and $\mathrm{PM}_{10}$ were 227 and $383 \mu \mathrm{g} \mathrm{m}^{-3}$, respectively, which increased significantly by 42 and $92 \mu \mathrm{g} \mathrm{m}^{-3}$ compared to the CAHP. The variations in $\mathrm{SO}_{2}$ and $\mathrm{NO}_{2}$ con- 
centrations during different stages of TECA were similar to those of $\mathrm{PM}_{2.5}$ and $\mathrm{PM}_{10}$ concentrations. The $P_{\mathrm{SO}_{2}}$-heating

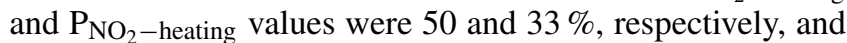

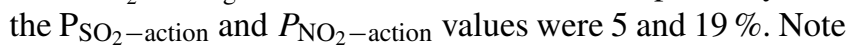
that the mean concentration of $\mathrm{CO}$ in Shijiazhuang City varied from $2.2 \mathrm{mg} \mathrm{m}^{-3}$ during the NCANHP to $5.5 \mathrm{mg} \mathrm{m}^{-3}$ during the ACA period, which showed an increasing tendency (Fig. 3). Because CO was mainly produced from the uncompleted combustion of fossil fuels, the usage of domestic coal might increase with the gradual decrease in temperature from the NCANHP $\left(8.4^{\circ} \mathrm{C}\right)$ to the ACA period $\left(0.7^{\circ} \mathrm{C}\right)$ (Table 1). Meanwhile, it can also be inferred that the control of domestic coal during the TECA period in Shijiazhuang City showed little efficiency. Because of the lack of emission inventories for domestic coal or small-boiler coal in Shijiazhuang, the control measures were less targeted. Additionally, the concentrations of $\mathrm{O}_{3}$ during different stages of TECA were lower compared to other pollutants (Figs. 2 and 3). Overall, the control measures of emission sources in Shijiazhuang during the TECA period were effective, while the coal heating for winter and the unfavourable meteorological conditions during the CAHP had an offset effect on the efforts of control measures for pollutant sources to some extent. The average wind speed during the CAHP $\left(0.4 \mathrm{~m} \mathrm{~s}^{-1}\right.$ on average) was lower than that during the other stages of the TECA period $\left(0.5-0.7 \mathrm{~m} \mathrm{~s}^{-1}\right.$ on average) (Table 1), and the wind directions were changeable (Fig. S1), which was in favour of the accumulation of atmospheric pollutants, thus causing the concentrations of atmospheric pollutants to increase during the CAHP. Note that the heights of the mixed layer showed a noticeably decreasing tendency from the NCANHP (540 m on average) and the NCAHP ( $590 \mathrm{~m}$ on average) to the ACA ( $431 \mathrm{~m}$ on average), and the height of the mixed layer during the CAHP was only $474 \mathrm{~m}$ on average (Table 1). The decrease in the height of the mixed layer can cause the concentrations of atmospheric pollutants near the ground to be significantly compressed and subsequently enhanced. In addition, during the CAHP, the multidirectional air masses that mainly originated from BeijingTianjin-Hebei and its surrounding areas (e.g. Henan, Shandong, and south of Hebei) displayed an overlap with each other in Shijiazhuang (Fig. S7) and further aggravated the level of air pollution in Shijiazhuang.

\subsubsection{Spatial variation}

The concentration variations in $\mathrm{PM}_{2.5}, \mathrm{PM}_{10}$, and related gaseous pollutants $\left(\mathrm{SO}_{2}, \mathrm{NO}_{2}, \mathrm{CO}\right.$, and $\left.\mathrm{O}_{3}\right)$ during the four stages (NCANHP, NCAHP, CAHP, and ACA) in an urban area and suburb in Shijiazhuang are shown in Figs. 3 and 5. During the NCANHP, the average concentrations of $\mathrm{PM}_{2.5}$ in an urban area and suburb were 166 and $152 \mu \mathrm{g} \mathrm{m}^{-3}$, respectively. The concentrations of $\mathrm{PM}_{2.5}$ in an urban area and suburb increased significantly during the NCAHP ( $t$ test, $p<0.01)$. The meanly increased concentration of $\mathrm{PM}_{2.5}$ $\left(46 \mu \mathrm{g} \mathrm{m}^{-3}\right)$ in an urban area was higher than that in the sub-

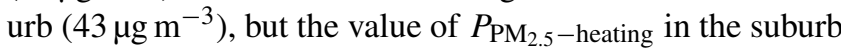
$(29 \%)$ was higher than that in the urban area (27\%) (Fig. 4). Note that the mean concentration of $\mathrm{PM}_{2.5}$ in the urban area was up to $243 \mu \mathrm{g} \mathrm{m}^{-3}$ during the CAHP, which showed an increasing tendency, and the $P_{\mathrm{PM}_{2.5}}$-action value was $-15 \%$ (Fig. 4), likely due to the unfavourable meteorological conditions such as lower wind speed $\left(0.4 \mathrm{~m} \mathrm{~s}^{-1}\right)$ and lower height of the mixed layer (474 m) (Table 1 and Fig. S7). Conversely, compared to the NCAHP, the concentrations of $\mathrm{PM}_{2.5}$ in the suburb (a mean of $161 \mu \mathrm{g} \mathrm{m}^{-3}$ ) decreased significantly during the CAHP ( $t$ test, $p<0.01$ ), and the $P_{\mathrm{PM}_{2.5} \text {-action was }}$ up to $18 \%$ (Fig. 4), indicating that the control measures of $\mathrm{PM}_{2.5}$ sources in the suburb might be more effective than in the urban area. The tendency of $\mathrm{SO}_{2}$ concentrations during different stages of TECA (except the ACA period) was similar to that of $\mathrm{PM}_{2.5}$. The $P_{\mathrm{SO}_{2}}$-heating and $P_{\mathrm{SO}_{2} \text {-action values }}$ in the urban area were up to 58 and $-4 \%$, respectively, and were up to 47 and $8 \%$ in the suburb during the TECA period (Fig. 4). However, the concentrations of $\mathrm{SO}_{2}$ in the urban area and suburb decreased remarkably during the ACA compared to the CAHP ( $t$ test, $p<0.01$ ), probably due to the effective control measures.

During the NCANHP, the average concentrations of $\mathrm{PM}_{10}$ in the urban area and suburb were 280 and $242 \mu \mathrm{g} \mathrm{m}^{-3}$, respectively. Then, the meanly increased concentrations in the urban area and suburb were up to 65 and $64 \mu \mathrm{g} \mathrm{m}^{-3}$ during the NCAHP, which were comparable with each other.

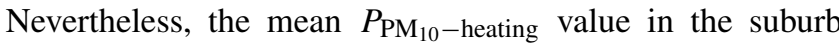
(26\%) was higher than that in the urban area (23\%) (Fig. 4). During the CAHP, the meanly decreased concentration of $\mathrm{PM}_{10}$ in the urban area was $1 \mu \mathrm{g} \mathrm{m}^{-3}$, and noticeably lower than that of the suburb $\left(36 \mu \mathrm{g} \mathrm{m}^{-3}\right)$. Furthermore, the mean $P_{\mathrm{PM}_{10}-\text { action values in the urban area and suburb were } 0.4 \text { and }}$ $12 \%$, respectively (Fig. 4). It can be seen that the control of $\mathrm{PM}_{10}$ sources in the suburb was more effective compared to the urban area, in the case of exclusion of unfavourable meteorological conditions (Table 1 and Fig. S7), probably related to more than 700 enterprises that mainly carried out ore mining and stone processing in the suburb that were closed down (Tables S1 and S5). The tendency of $\mathrm{NO}_{2}$ concentrations in the urban area and suburb was similar to that of $\mathrm{PM}_{10}$ during different stages of the TECA period. The mean $P_{\mathrm{NO}_{2}}$-heating values in the urban area and suburb were up to 31 and $34 \%$,

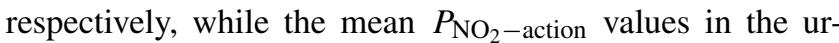
ban area and suburb were up to 17 and $21 \%$, respectively. Note that the concentrations of CO in the urban area and suburb showed an increasing tendency from the NCANHP (2.1$2.4 \mathrm{mg} \mathrm{m}^{-3}$ ) to the ACA period $\left(5.5 \mathrm{mg} \mathrm{m}^{-3}\right.$ ) (Fig. 3). The

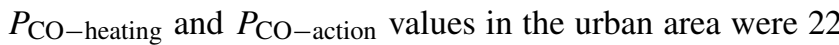
and $-15 \%$, respectively, while those in the suburb were 32 and $-20 \%$ during the TECA period. In addition, as shown in Fig. 5, the concentrations of $\mathrm{CO}$ in the eastern and northern suburbs in Shijiazhuang were significantly higher than those of urban areas ( $t$ test, $p<0.01)$. Note that the concentrations 
(a) NCANHP
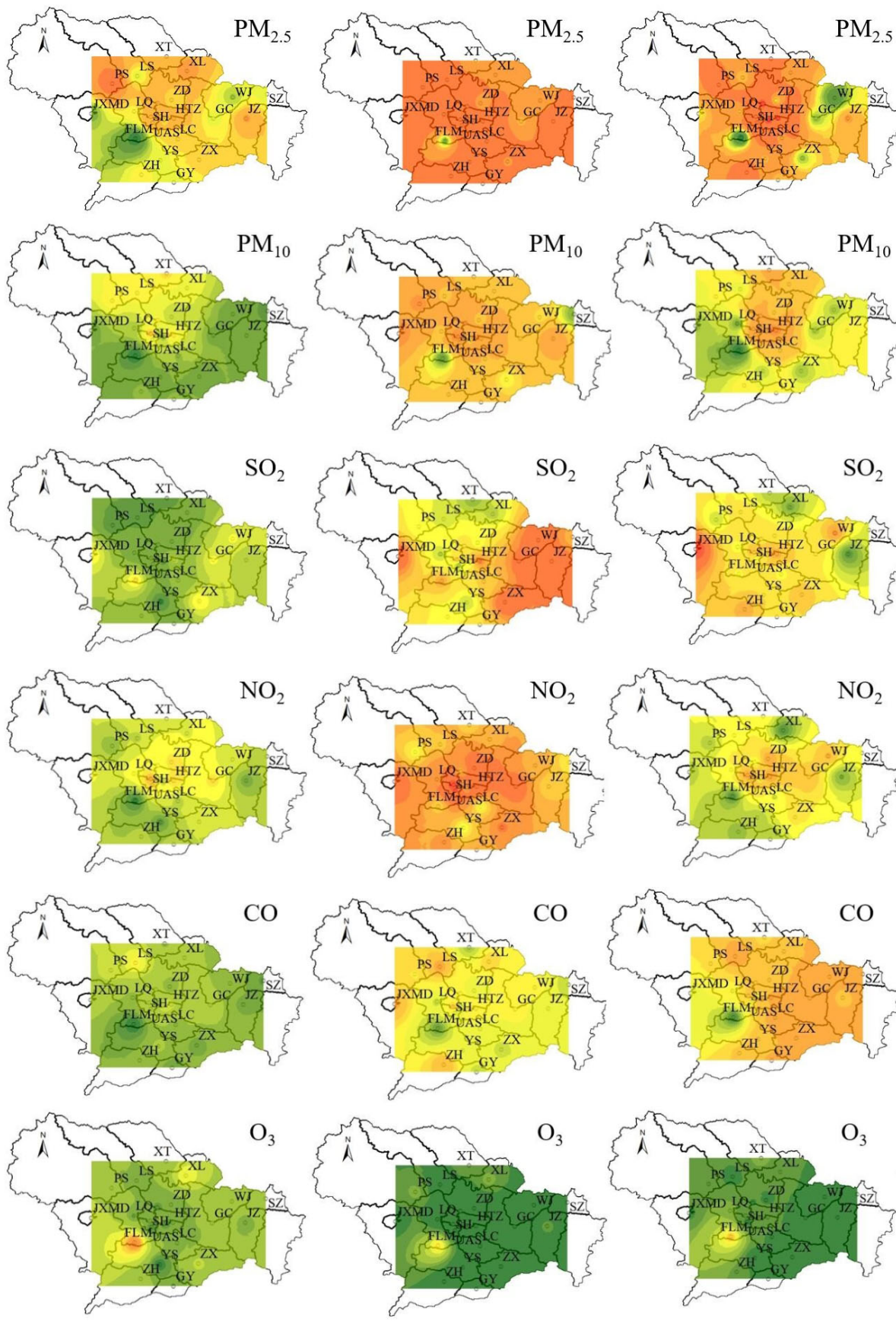

(c) CAHP

(d) ACA
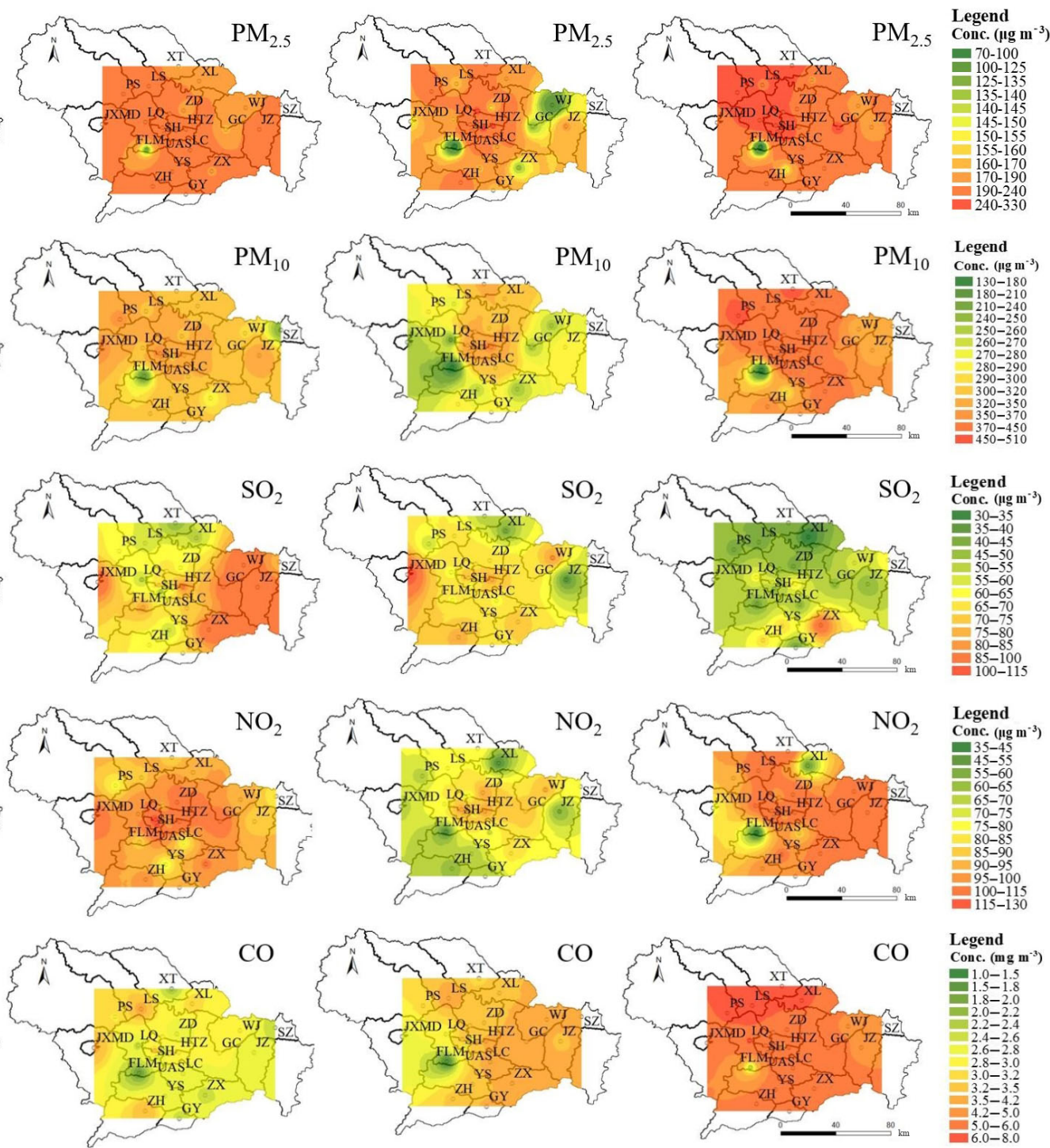

Figure 5. The spatial variations in atmospheric pollutants $\left(\mathrm{PM}_{2.5}, \mathrm{PM}_{10}, \mathrm{SO}_{2}, \mathrm{NO}_{2}, \mathrm{CO}\right.$, and $\left.\mathrm{O}_{3}\right)$ during the four stages (NCANHP, NCAHP, CAHP, and ACA) of the TECA period in Shijiazhuang. The pictures were produced using the ArcGIS-based kriging interpolation method.

of $\mathrm{O}_{3}$ in the urban area and suburb were lower during different stages of TECA (Fig. 5). Overall, during the TECA period, the effect of control measures for atmospheric pollutant sources in the suburb was better than in the urban area, especially for the effect of control measures for particulate matter sources. The effect of control measures for $\mathrm{CO}$ was not notable during the TECA period, especially in the sub- urb, likely due to the increasing usage of domestic coal in the suburb along with the decreasing temperature (Table 1).

\subsection{Variations in chemical species in $\mathbf{P M}_{2.5}$}

The average concentrations of chemical species in $\mathrm{PM}_{2.5}$ in Shijiazhuang during the whole sampling period are shown in 


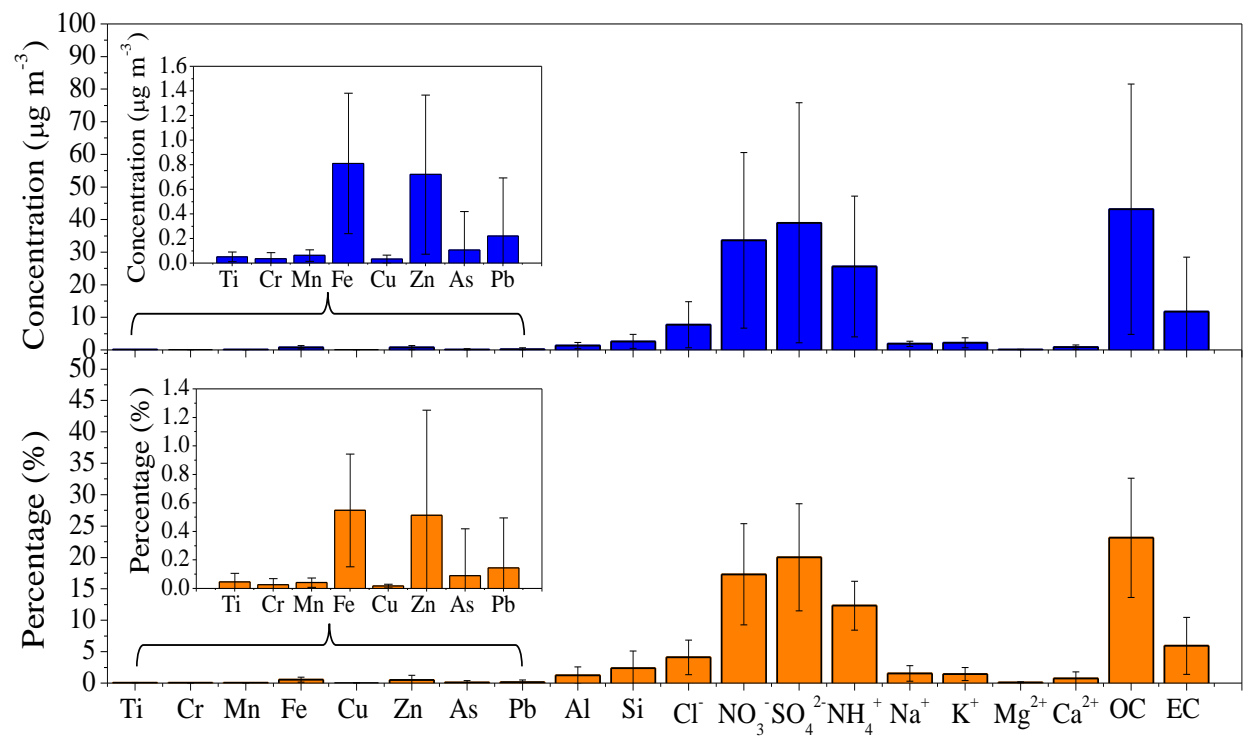

Figure 6. The average concentrations and percentages of chemical species in $\mathrm{PM}_{2.5}$ in Shijiazhuang during the whole sampling period: 24 November 2015 to 9 January 2017. The error bar represents the standard deviation.

Fig. 6. The annual mean concentrations of $\mathrm{OC}, \mathrm{SO}_{4}^{2-}, \mathrm{NO}_{3}^{-}$, and $\mathrm{NH}_{4}^{+}$in $\mathrm{PM}_{2.5}$ were 43.1, 39.0, 33.6, and $25.6 \mu \mathrm{g} \mathrm{m} \mathrm{m}^{-3}$, respectively, and their contributions to $\mathrm{PM}_{2.5}$ were up to 23.1, $20.0,17.3$, and $12.3 \%$, respectively. The annual mean concentrations of $\mathrm{EC}$ and $\mathrm{Cl}^{-}$were 11.7 and $7.7 \mu \mathrm{g} \mathrm{m}^{-3}$, respectively, which accounted for 5.9 and $4.1 \%$ of $\mathrm{PM}_{2.5}$. Note that the annual mean concentrations of elements in $\mathrm{PM}_{2.5}$ were relatively lower, which varied from 0.03 to $2.6 \mu \mathrm{g} \mathrm{m}^{-3}$, accounting for $0.02-2.4 \%$ of $\mathrm{PM}_{2.5}$. Compared to other elements, the annual mean concentrations of $\mathrm{Si}\left(2.6 \mu \mathrm{g} \mathrm{m}^{-3}\right)$ and $\mathrm{Al}\left(1.4 \mu \mathrm{g} \mathrm{m}^{-3}\right)$ were relatively higher during the whole sampling period, which accounted for 2.4 and $1.2 \%$ of $\mathrm{PM}_{2.5}$, respectively. In this study, the annual mean concentrations of $\mathrm{OC}, \mathrm{SO}_{4}^{2-}, \mathrm{NO}_{3}^{-}$, and $\mathrm{NH}_{4}^{+}$in Shijiazhuang were clearly higher than Beijing (Gao et al., 2016), Tianjin (Wu et al., 2015), Jinan (Gao et al., 2011), Shanghai (H. L. Wang et al., 2016), Chengdu (Tao et al., 2013b), Xi' an (P. Wang et al., 2015), Hangzhou (Liu et al., 2015), and Heze (Liu et al., 2017a).

The values of $P_{i-\text { heating }}$ and $P_{i-\text { action }}$ of different chemical species in $\mathrm{PM}_{2.5}$ were calculated by using Eqs. (8) and (9). The variations in chemical species in $\mathrm{PM}_{2.5}$ during the four stages of the TECA and the values of $P_{i-\text { heating }}$ and $P_{i-\text { action }}$ in Shijiazhuang are shown in Figs. 7 and 8. Compared to the NCANHP, the concentrations of chemical species during the NCAHP showed a significantly increased tendency ( $t$ test, $p<0.01$ ); the concentrations of $\mathrm{SO}_{4}^{2-}, \mathrm{Cl}^{-}, \mathrm{OC}, \mathrm{EC}$, $\mathrm{Si}, \mathrm{Al}, \mathrm{Ca}^{2+}$, and $\mathrm{Mg}^{2+}$ increased by $7.9,3.7,6.7,3.2,1.6$, $0.6,0.4$, and $0.1 \mu \mathrm{g} \mathrm{m}^{-3}$, respectively, and the $P_{i \text {-heating val- }}$ ues of these species were up to $30.0,40.2,14.6,22.1,78.8$, 63.5, 47.4, and $45.9 \%$, respectively, during the NCAHP. As these species (i.e. $\mathrm{SO}_{4}^{2-}, \mathrm{Cl}^{-}, \mathrm{OC}, \mathrm{EC}, \mathrm{Si}, \mathrm{Al}, \mathrm{Ca}^{2+}$, and
$\mathrm{Mg}^{2+}$ ) were closely associated with coal combustion (Cao et al., 2011; Liu et al., 2015; Liu et al., 2016; Liu et al., $2017 \mathrm{a}, \mathrm{b}, \mathrm{c}$ ), coal combustion for heating in winter probably had a great impact on increasing these chemical species in $\mathrm{PM}_{2.5}$. Furthermore, compared to the NCANHP, the concentrations of $\mathrm{Cr}, \mathrm{Cu}, \mathrm{Fe}, \mathrm{Mn}, \mathrm{Ti}, \mathrm{Zn}$, and $\mathrm{Pb}$ increased by $0.02,0.02,0.34,0.02,0.02,0.28$, and $0.07 \mu \mathrm{g} \mathrm{m}^{-3}$, respec-

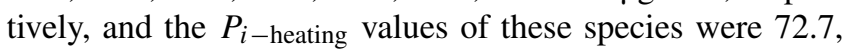
$33.1,34.4,21.0,45.8,48.3$, and $36.2 \%$, respectively, during the NCAHP. $\mathrm{Cr}, \mathrm{Cu}, \mathrm{Fe}, \mathrm{Mn}, \mathrm{Ti}, \mathrm{Zn}$, and $\mathrm{Pb}$ were closely related to industrial sources (Kabala and Singh, 2001; Morishita et al., 2011; Mansha et al., 2012; Liu et al., 2015; Yao et al., 2016); thus, the industrial emissions might have a higher influence on $\mathrm{PM}_{2.5}$ during the NCAHP than during the NCANHP. Also, it might be closely associated with the unfavourable meteorological factors (Table 1 and Fig. S7).

Compared to the NCAHP, the concentrations of $\mathrm{SO}_{4}^{2-}$, $\mathrm{Cl}^{-}$, OC, and EC during the CAHP increased by $16.8,0.3$, 19.8 , and $14.6 \mu \mathrm{g} \mathrm{m}^{-3}$, respectively, and the $P_{i-\text { action }}$ values were up to $-48.8,-2.0,-37.3$, and $-83.0 \%$, respectively, during the CAHP. As coal combustion was an important source of $\mathrm{SO}_{4}^{2-}, \mathrm{Cl}^{-}, \mathrm{OC}$, and EC (Cao et al., 2011; Liu et al., 2015; Liu et al., 2016, 2017a, b, c), it can be inferred that the influence of coal combustion might increase noticeably during the CAHP compared to the NCAHP, which was likely due to the increased usage of coal for domestic heating during winter (Table 1). Additionally, unfavourable meteorological conditions during the CAHP can have an offset effect on the control measures for coal combustion sources. As also in shown Fig. 5, the concentrations of $\mathrm{CO}$ during the CAHP were higher than those during the NCAHP, especially in rural areas. Furthermore, OC and EC were associated with 


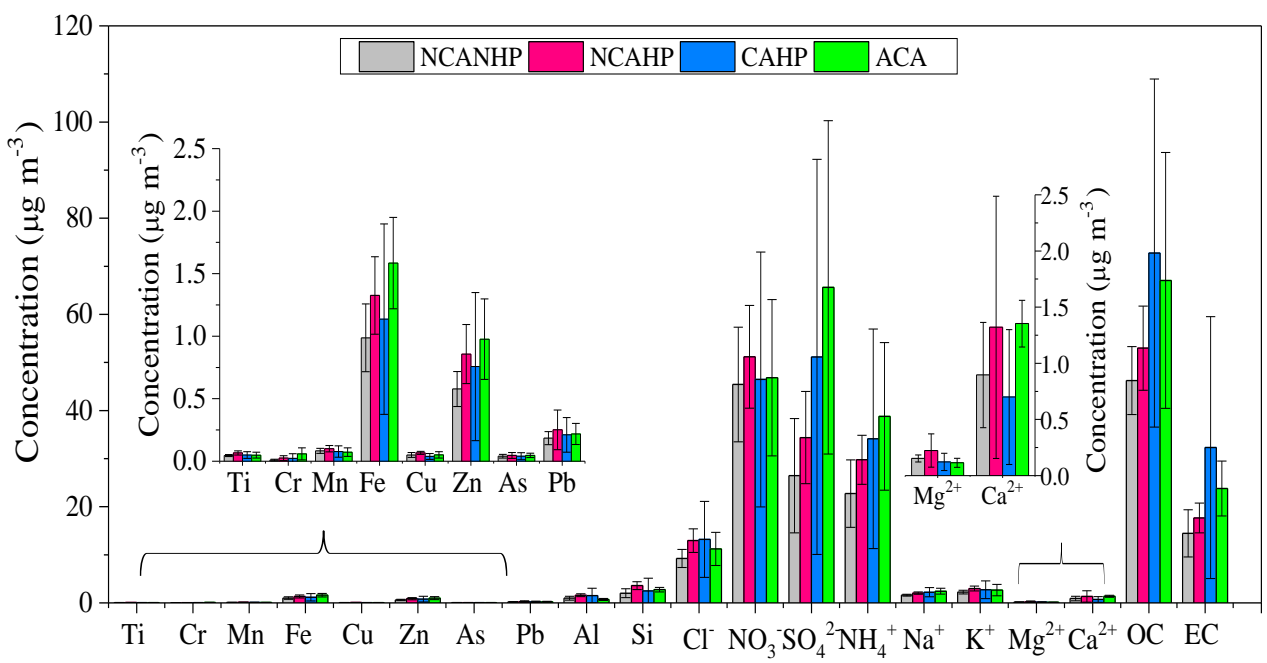

Figure 7. The variations in chemical species in $\mathrm{PM}_{2.5}$ during the four stages (NCANHP, NCAHP, CAHP, and ACA) of the TECA period. The error bar represents the standard deviation.

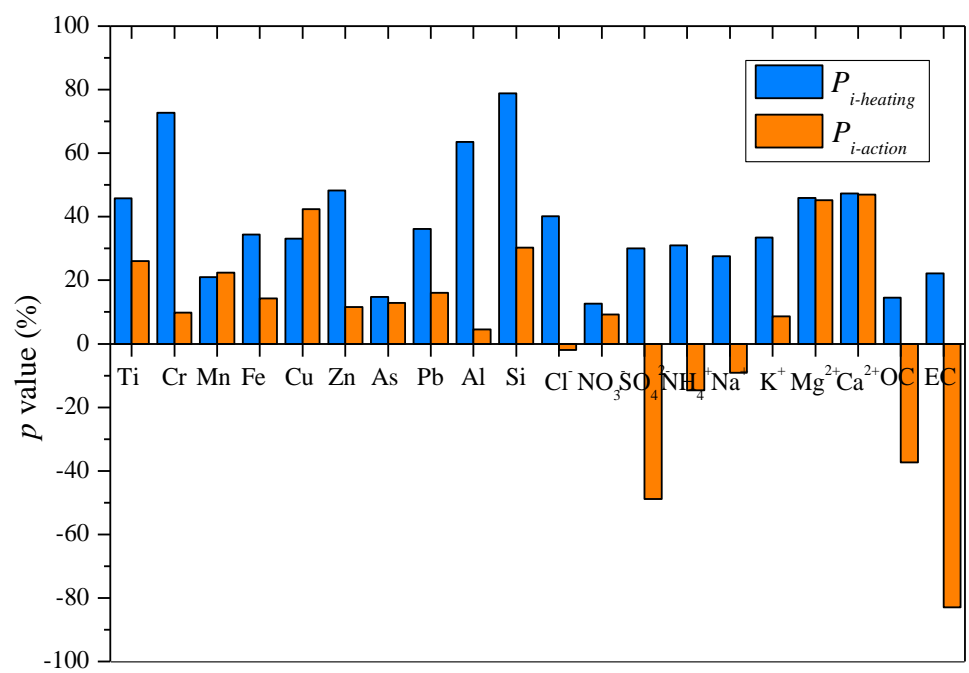

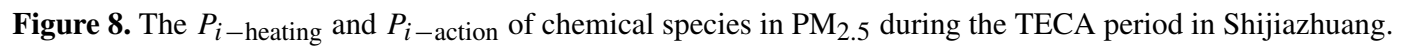

vehicle exhaust (Liu et al., 2016, 2017a, b); thus, the effect of motor vehicle management and control measures during the CAHP might be offset by the unfavourable meteorological conditions to some extent during the CAHP (Table 1 and Fig. S7). However, compared to the NCAHP, the concentrations of $\mathrm{Si}, \mathrm{Al}, \mathrm{Ca}^{2+}$, and $\mathrm{Mg}^{2+}$ during the CAHP decreased by $1.1,0.1,0.6$, and $0.1 \mathrm{\mu g} \mathrm{m}^{-3}$, respectively, and the $P_{i-\text { action }}$ values were up to $30.3,4.5,47.0$, and $45.2 \%$, respectively. $\mathrm{As} \mathrm{Si}, \mathrm{Al}, \mathrm{Ca}^{2+}$, and $\mathrm{Mg}^{2+}$ mainly originated from the crustal dust (Shen et al., 2010; Liu et al., 2016; P. Wang et al., 2015; H. N. Yang et al., 2016), the influence of crustal dust on $\mathrm{PM}_{2.5}$ during the CAHP might decrease clearly compared to the NCAHP. This is closely related to the control measures on dust emission during the TECA period (as shown in Sect. 2.5). In general, in regard to the variation in $\mathrm{PM}_{2.5}$ speciation, there was no doubt that the TECA had a certain positive environmental effect on the improvement of air quality. However, the ambient pollutant concentration was impacted by not only the emission sources but also the meteorological conditions, regional background level, and distant transportation; it was understandable that the concentration of CO had a rebound effect during the CAHP as the height of the mixing layer was only $474 \mathrm{~m}$ and wind speed was low at $0.4 \mathrm{~m} \mathrm{~s}^{-1}$.

\subsection{Variations in $\mathbf{P M}_{2.5}$ source contributions}

The filter membrane samples of $\mathrm{PM}_{2.5}$ were collected at three sites (LQ, LC, and TSMS) in Shijiazhuang from 24 


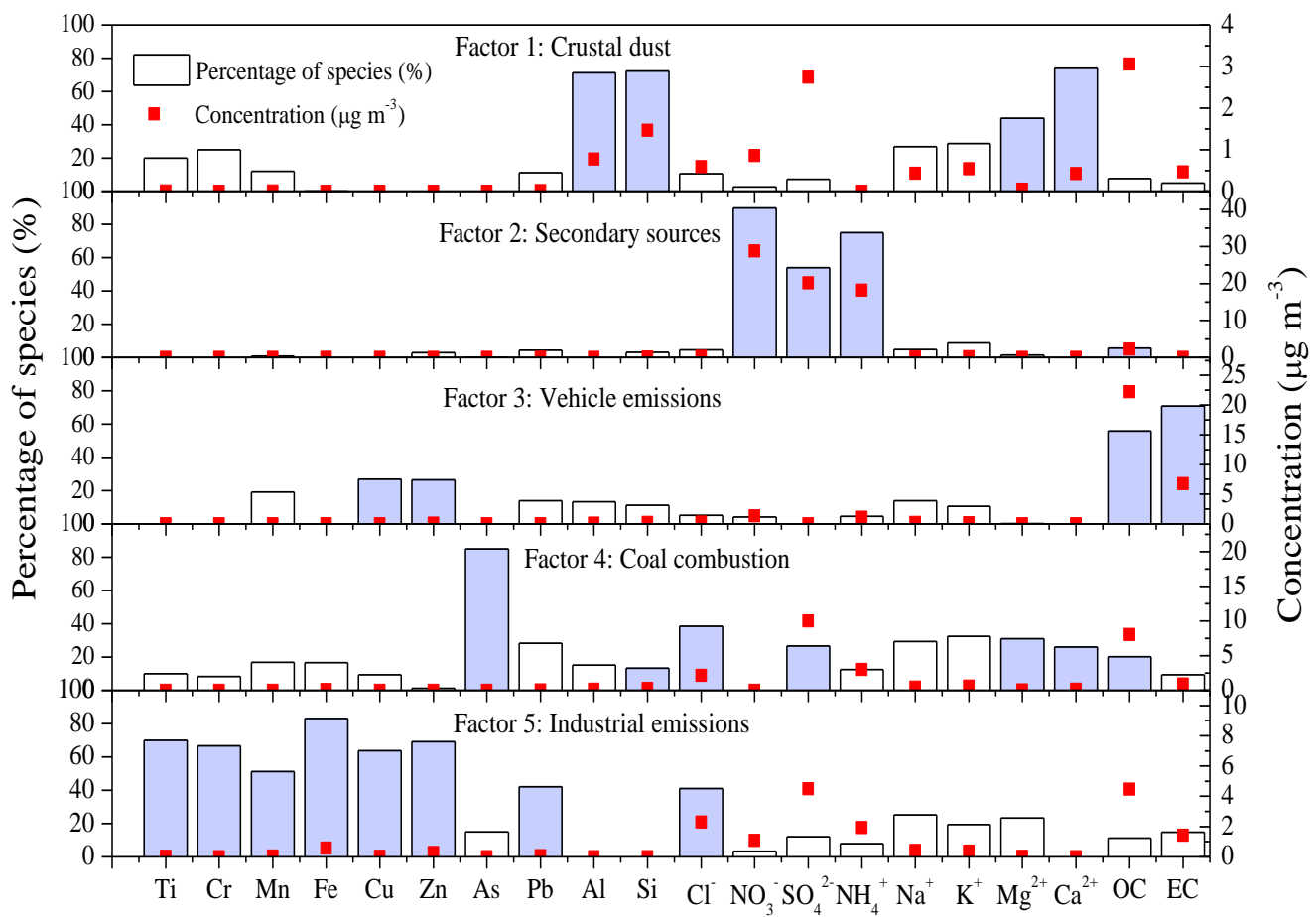

Figure 9. Source profiles obtained with the PMF for $\mathrm{PM}_{2.5}$. Filled bars identify the species that mainly characterize each factor profile.

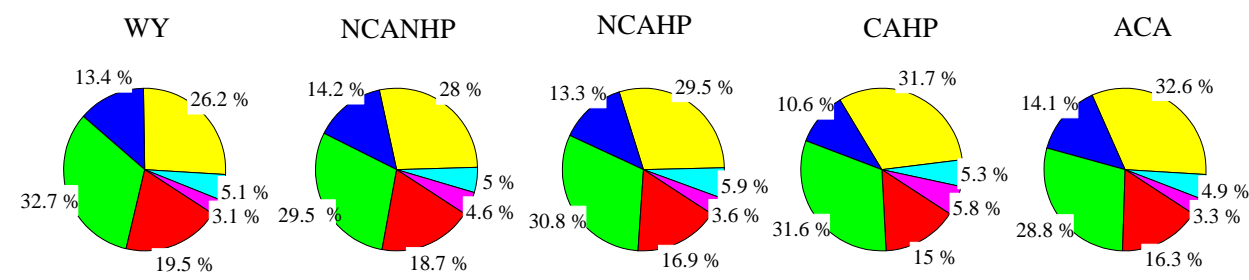

Crustal dust Secondary sources Vehicle emissions Coal combustion Industrial emissions Unresolved sources

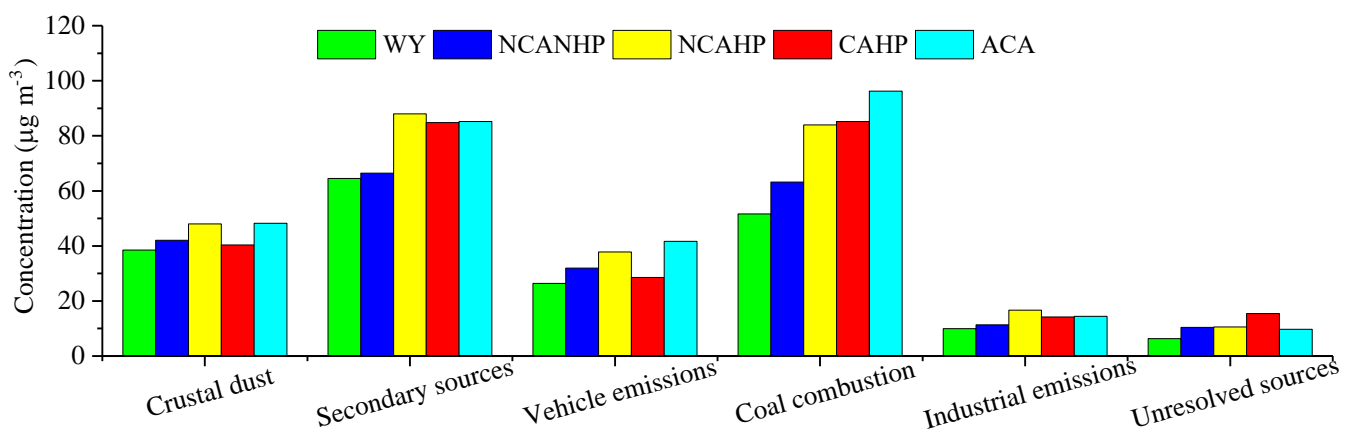

Figure 10. Source contributions of $\mathrm{PM}_{2.5}$ during different stages in Shijiazhuang. WY represents the whole year: 24 November 2015 to 9 January 2017.

November 2015 to 9 January 2017, and source apportionment was carried out by using EPA PMF 5.0. Five factors were also identified during the period (Figs. 9 and 10). The chemical profile of factor 1 was mainly represented by $\mathrm{Si}$ $(72.3 \%), \mathrm{Ca}^{2+}(74.0 \%), \mathrm{Mg}^{2+}(43.9 \%)$, and $\mathrm{Al}(71.3 \%)$, which were derived mainly from crustal dust (Shen et al., 2010; P. Wang et al., 2015; Liu et al., 2016). Thus, factor 1 was viewed as crustal dust. The contribution proportions of factor 1 to $\mathrm{PM}_{2.5}$ decreased from $19.5 \%\left(38.5 \mu \mathrm{g} \mathrm{m}^{-3}\right)$ during the whole year (WY), $18.7 \%\left(42.1 \mu \mathrm{g} \mathrm{m}^{-3}\right)$ during 
the NCANHP, and $16.9 \%\left(48.0 \mu \mathrm{g} \mathrm{m}^{-3}\right)$ during the NCAHP to $15.0 \%\left(40.3 \mu \mathrm{g} \mathrm{m}^{3}\right)$ during the CAHP, and increased up to $16.3 \%\left(48.3 \mu \mathrm{g} \mathrm{m}^{-3}\right)$ during the ACA. The main species of factor 2 were $\mathrm{SO}_{4}^{2-}(53.9 \%), \mathrm{NO}_{3}^{-}(89.8 \%)$, and $\mathrm{NH}_{4}^{+}(75.0 \%)$. Therefore, factor 2 was easily identified as secondary sources (Santacatalina et al., 2010; Srimuruganandam and Nagendra, 2012; Liu et al., 2015; Liu et al., 2016, 2017a). The contribution proportions of factor 2 to $\mathrm{PM}_{2.5}$ ranged from $29.5 \%\left(66.4 \mu \mathrm{g} \mathrm{m}^{-3}\right)$ during the NCANHP, $30.8 \%\left(87.9 \mu \mathrm{g} \mathrm{m}^{-3}\right)$ during the NCAHP, and $31.6 \%\left(84.8 \mu \mathrm{g} \mathrm{m}^{-3}\right)$ during the CAHP to $32.7 \%$ $\left(64.6 \mu \mathrm{g} \mathrm{m}^{-3}\right)$ during the WY, and decreased to $28.8 \%$ $\left(85.2 \mu \mathrm{g} \mathrm{m}^{-3}\right)$ during the ACA. Factor 3 was represented by relatively high loadings of OC $(55.9 \%)$, EC (70.9\%), $\mathrm{Cu}(26.9 \%)$, and $\mathrm{Zn}(26.5 \%)$. OC and EC are generally predominant in the reported source profile of vehicle exhaust (Yao et al., 2016; Liu et al., 2016, 2017a), Zn is widely used as an additive for lubricant in two-stroke engines, and $\mathrm{Cu}$ is closely associated with brake wear (Begum et al., 2004; Canha et al., 2012; Shafer et al., 2012; Lin et al., 2015; Liu et al., 2017a). Therefore, factor 3 was identified as vehicle emissions. The contribution proportions of factor 3 to $\mathrm{PM}_{2.5}$ decreased from $14.2 \%\left(32.0 \mu \mathrm{g} \mathrm{m}^{-3}\right)$ during the NCANHP, $13.4 \%\left(26.4 \mu \mathrm{g} \mathrm{m}^{3}\right)$ during the WY, and $13.3 \%\left(37.8 \mathrm{\mu g} \mathrm{m}^{-3}\right)$ during the NCAHP to $10.6 \%$ $\left(28.5 \mu \mathrm{g} \mathrm{m}^{-3}\right)$ during the CAHP, and increased to $14.1 \%$ $\left(41.7 \mu \mathrm{g} \mathrm{m}^{-3}\right)$ during the ACA. Factor 4 was characterized by the high contributions of $\mathrm{Ca}^{2+}(26.0 \%), \mathrm{Mg}^{2+}(31.0 \%)$, Si $(13.3 \%)$, As $(84.9 \%), \mathrm{Cl}^{-}(38.6 \%)$, OC $(20.2 \%)$, and $\mathrm{SO}_{4}^{2-}(26.7 \%)$, and the combination of these species in factor 4 allowed us to infer they were co-emissions from coal combustion (Cao et al., 2011; Zhang et al., 2011; Liu et al., 2015; Liu et al., 2016, 2017a, c). Therefore, factor 4 was identified as coal combustion. The contribution proportions of factor 4 to $\mathrm{PM}_{2.5}$ increased from $26.2 \%$ $\left(51.7 \mu \mathrm{g} \mathrm{m}^{-3}\right)$ during the WY, $28.0 \%\left(63.2 \mu \mathrm{g} \mathrm{m}^{-3}\right)$ during the NCANHP, and $29.5 \%\left(84.0 \mu \mathrm{g} \mathrm{m}^{-3}\right)$ during the NCAHP to $31.7 \%\left(85.2 \mu \mathrm{g} \mathrm{m}^{-3}\right)$ during the CAHP, and lightly increased to $32.6 \%\left(96.3 \mu \mathrm{g} \mathrm{m}^{-3}\right)$ during the ACA. Factor 5 was identified as industrial emissions, with high loadings of $\mathrm{Cr}(66.7 \%), \mathrm{Cu}(63.7 \%), \mathrm{Fe}(83.2 \%), \mathrm{Mn}(51.3 \%)$, Ti (70.0\%), $\mathrm{Zn}(69.2 \%), \mathrm{Pb}(42.1 \%)$, and $\mathrm{Cl}^{-}$(41.0\%) (Morishita et al., 2011; Mansha et al., 2012; Almeida et al., 2015; Liu et al., 2015; Liu et al., 2016; Yao et al., 2016). The contribution proportions of factor 5 to $\mathrm{PM}_{2.5}$ ranged from $5.0 \%$ $\left(11.3 \mu \mathrm{g} \mathrm{m}^{-3}\right)$ during the NCANHP and $5.1 \%\left(10.0 \mu \mathrm{g} \mathrm{m}^{-3}\right)$ during the WY to $5.9 \%\left(16.7 \mu \mathrm{g} \mathrm{m}^{-3}\right)$ during the NCAHP, and decreased to $5.3 \%\left(14.2 \mu \mathrm{g} \mathrm{m}^{-3}\right)$ during the CAHP and $4.9 \%\left(14.4 \mu \mathrm{g} \mathrm{m}^{-3}\right)$ during the ACA. Note that the contribution of industrial emissions to $\mathrm{PM}_{2.5}$ was relatively lower than other sources (Fig. 10).

In general, crustal dust, secondary sources, vehicle emissions, coal combustion, and industrial emissions were identified as $\mathrm{PM}_{2.5}$ sources in Shijiazhuang (Fig. 9). Compared to the WY and NCANHP, the contribution concentrations and proportions of coal combustion to $\mathrm{PM}_{2.5}$ increased significantly during other stages of the TECA period (Fig. 10), which was closely associated with the coal heating for winter (Liu et al., 2016) and the unfavourable meteorological conditions (Table 1 and Fig. S7). The contribution concentrations and proportions of crustal dust and vehicle emissions to $\mathrm{PM}_{2.5}$ decreased noticeably during the CAHP compared to other stages of the TECA period (Fig. 10). This indicated that the control effects of motor vehicles and crustal dust were remarkable during the CAHP, even under unfavourable meteorological conditions (Table 1), and the results were consistent with the above analysis. The contribution proportions of secondary sources to $\mathrm{PM}_{2.5}$ during the CAHP showed little change compared to other stages of the TECA period (Fig. 10). However, compared to the WY and NCANHP, the contribution concentrations of secondary sources to $\mathrm{PM}_{2.5}$ increased significantly during the NCAHP, CAHP, and ACA (Fig. 10), likely due to high concentrations of gaseous precursors (i.e. $\mathrm{SO}_{2}$ and $\mathrm{NO}_{2}$ ) (Fig. 5), unfavourable meteorological conditions (Table 1), and frequent hazy events during these periods, when there were significant secondary reactions (Han et al., 2014; J. J. Li et al., 2016). In addition, it also illustrated that the discharge of atmospheric pollutants might still be enormous even under such strict control measures. Note that the contribution concentrations and proportions of industrial emissions to $\mathrm{PM}_{2.5}$ during the CAHP decreased noticeably compared to the NCAHP (Fig. 10), indicating that the control of industrial emissions was also effective during the CAHP.

P. L. Chen et al. (2016) reported that the concentrations of particles during the 2014 Youth Olympic Games (YOG) period (August) were much lower than the before-games period (July) and after-games period (September). Furthermore, fugitive dusts, construction dusts, and secondary sulfate aerosol decreased obviously during the YOG, which means mitigation measures have played an effective role in the reduction of particulate matter. Wang et al. (2017) found that the contributions of vehicles, industrial sources, fugitive dust, and other sources decreased 13.5-14.7, 10.7-11.2, 4.55.6, and $1.7-2.7 \%$, respectively, during the Asia-Pacific Economic Cooperation (APEC) and the 2015 China Victory Day Parade, compared to the period before the control actions. Guo et al. (2013) found that primary vehicle contributions were reduced by $30 \%$ at the urban site and $24 \%$ at the rural site, compared with the non-controlled period before the 2008 Beijing Olympics. The reductions in coal combustion contributions were $57 \%$ at the Peking University (PKU) site and $7 \%$ at the Yufa site. As we can see, these control actions on the strict measures taken for emission sources during the international events held in China, including the TECA in Shijiazhuang, were all very important practical exercises and rarely scientific experiments. However, they cannot be advocated as the normalized control measures for atmospheric pollution in China. These strict measures taken during these periods were temporary, and there was a normal recovery of 


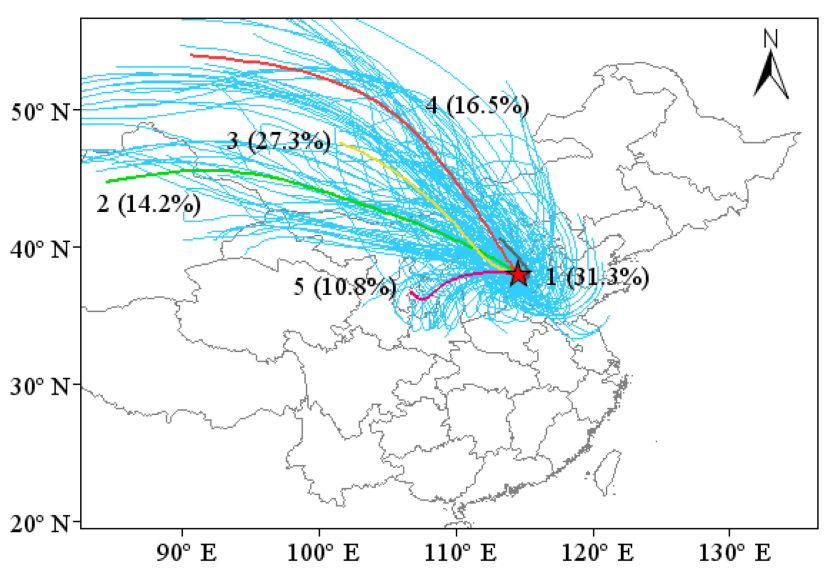

Figure 11. Five clusters of the $72 \mathrm{~h}$ air mass backward trajectories during the CAHP. The red star represents Shijiazhuang City.

all the emissions after the operation. Once adverse weather conditions occur, haze events may continue to happen. In short, the direct cause of the severe atmospheric pollution in China is that the emission of pollutants is beyond the air environment's self-purification capacity and is caused by an unreasonable and unhealthy pattern for economic development in China.

\subsection{Backward trajectory and PSCF analysis}

The backward trajectory analysis was used to identify the transport pathways of the air mass during the CAHP. In terms of the directions and travelled areas, these trajectories were divided into five groups (Fig. 11). Trajectory cluster 1 , accounting for $31.3 \%$ of the total, originated from Shanxi Province and passed over the north of Hebei before arriving at Shijiazhuang. Trajectory cluster 1 reflected the features of small-scale, short-distance air mass transport (Fig. 11). The higher concentrations of $\mathrm{PM}_{10}\left(358 \mu \mathrm{g} \mathrm{m}^{-3}\right)$, $\mathrm{PM}_{2.5}\left(237 \mu \mathrm{g} \mathrm{m}^{-3}\right)$, and $\mathrm{CO}\left(3.9 \mathrm{mg} \mathrm{m}^{-3}\right)$ might be due to the variety of emission sources and the accumulation of pollutants from surrounding areas since the moving speed of the air mass in cluster 1 was much lower than other trajectories (Fig. 11 and Table 2). Trajectory clusters 2, 3, and 4 accounted for $58.0 \%$ of the total trajectories, and began from the northwest of China and passed through Inner Mongolia and Shanxi, showing the features of large-scale, longdistance air mass transport. The relatively lower concentrations of $\mathrm{PM}_{10}\left(189-290 \mu \mathrm{g} \mathrm{m}^{-3}\right), \mathrm{PM}_{2.5}\left(119-181 \mu \mathrm{g} \mathrm{m}^{-3}\right)$, $\mathrm{SO}_{2}\left(50-67 \mu \mathrm{g} \mathrm{m}^{-3}\right), \mathrm{NO}_{2}\left(58-78 \mu \mathrm{g} \mathrm{m}^{-3}\right)$, and $\mathrm{CO}(2.1-$ $3.0 \mathrm{mg} \mathrm{m}^{-3}$ ) were closely associated with the high moving speed of air mass (Fig. 11 and Table 2) and relatively less anthropogenic emission sources in the northwest of China. Trajectory cluster 5 mainly originated from Ningxia Province and passed over Shaanxi, Shanxi, and Hebei before arriving at Shijiazhuang, accounting for $10.8 \%$ of the total trajectories, showing the features of small-scale, short-distance air mass transport and significantly elevated levels of $\mathrm{PM}_{10}$ $\left(451 \mu \mathrm{g} \mathrm{m}^{-3}\right), \mathrm{PM}_{2.5}\left(303 \mu \mathrm{g} \mathrm{m}^{-3}\right), \mathrm{SO}_{2}\left(83 \mu \mathrm{g} \mathrm{m}^{-3}\right), \mathrm{NO}_{2}$ $\left(104 \mu \mathrm{g} \mathrm{m}^{-3}\right)$, and $\mathrm{CO}\left(4.8 \mathrm{mg} \mathrm{m}^{-3}\right)$ with trajectory cluster 5 possibly associated with the sources and accumulation of pollutants from surrounding areas. As it is well known that the Beijing-Tianjin-Hebei region is one of the most severely polluted areas in China (Gu et al., 2011; Zhao et al., 2012; Chen et al., 2013; Bi et al., 2014; Wang et al., 2014), it might be an important reason why the concentrations of atmospheric pollutants were higher with trajectory clusters 1 and 5 (Fig. 11 and Table 2).

In this study, the PSCF model was used to analyse the potential source areas of atmospheric pollutants by combining backward trajectories and the concentrations of atmospheric pollutants in Shijiazhuang during the CAHP, and the results were shown in Fig. 12. The values of the weighted potential source contribution function (WPSCF) of CO were higher in the north of Shaanxi, south of Shanxi, and central and southern Inner Mongolia, which were the main potential source areas of CO concentrations in Shijiazhuang (Fig. 12a). The WPSCF values of $\mathrm{NO}_{2}$ were higher in the north of Henan and Shaanxi, Hebei, Shanxi, and central and southern Inner Mongolia, which were the main potential source areas of $\mathrm{NO}_{2}$ concentrations in Shijiazhuang (Fig. 12b). The WP$\mathrm{SCF}$ values of $\mathrm{O}_{3}$ and $\mathrm{SO}_{2}$ were higher in the north of Henan and Shaanxi, Shanxi, and the south of Hebei, which were distinguished as major potential source areas of $\mathrm{O}_{3}$ and $\mathrm{SO}_{2}$ concentrations in Shijiazhuang (Fig. 12c, d). Moreover, the southwest of Shandong was also identified as the main potential source area of $\mathrm{SO}_{2}$ concentrations in Shijiazhuang. As for $\mathrm{PM}_{2.5}$ and $\mathrm{PM}_{10}$, the WPSCF values were higher in the south of Hebei, and east of Shanxi, which were identified as the main potential source areas of $\mathrm{PM}_{2.5}$ and $\mathrm{PM}_{10}$ concentrations in Shijiazhuang (Fig. 12e, f). Overall, the potential source areas of the atmospheric pollutants in Shijiazhuang were mainly concentrated in the surrounding regions of Shijiazhuang, including the south of Hebei and north of Henan and Shanxi. Previous studies also reported that Shanxi, Hebei, and Henan provinces had serious air pollution problems (Zhu et al., 2011; Kong et al., 2013; Feng et al., 2016; Meng et al., 2016), revealing the regional nature of the atmospheric pollution in the North China Plain. Therefore, there is an urgent need for making cross-boundary control policies in addition to local control measures given the high background level of pollutants.

\section{Conclusions}

The control measures of atmospheric pollution in Shijiazhuang were effective and an important step. Under unfavourable meteorological conditions, the mean concentrations of $\mathrm{PM}_{2.5}, \mathrm{PM}_{10}, \mathrm{SO}_{2}, \mathrm{NO}_{2}$, and chemical species $(\mathrm{Si}$, $\left.\mathrm{Al}, \mathrm{Ca}^{2+}, \mathrm{Mg}^{2+}\right)$ in $\mathrm{PM}_{2.5}$ during the CAHP significantly decreased compared to the NCAHP. Overall, the effects of control measures in suburbs were better than in the urban area, 
Table 2. The average concentrations of atmospheric pollutants in different clusters during the CAHPa

\begin{tabular}{lrrrrrrr}
\hline \multirow{2}{*}{ Clusters } & \multirow{2}{*}{\begin{tabular}{c} 
Probability of \\
\cline { 3 - 8 }
\end{tabular}} & \multicolumn{6}{c}{ Atmospheric pollutants $\left(\mu \mathrm{g} \mathrm{m}^{-3}\right)$} \\
\cline { 3 - 8 } & occurrence (\%) & $\mathrm{SO}_{2}$ & $\mathrm{NO}_{2}$ & $\mathrm{O}_{3}$ & $\mathrm{CO}\left(\mathrm{mg} \mathrm{m}^{-3}\right)$ & $\mathrm{PM}_{10}$ & $\mathrm{PM}_{2.5}$ \\
\hline 1 & 31.3 & 68 & 88 & 14 & 3.9 & 358 & 237 \\
2 & 14.2 & 67 & 78 & 24 & 3.0 & 290 & 181 \\
3 & 27.3 & 65 & 69 & 20 & 2.8 & 232 & 152 \\
4 & 16.5 & 50 & 58 & 27 & 2.1 & 189 & 119 \\
5 & 10.8 & 83 & 104 & 16 & 4.8 & 451 & 303 \\
\hline
\end{tabular}

a CAHP represents the control action and heating period.
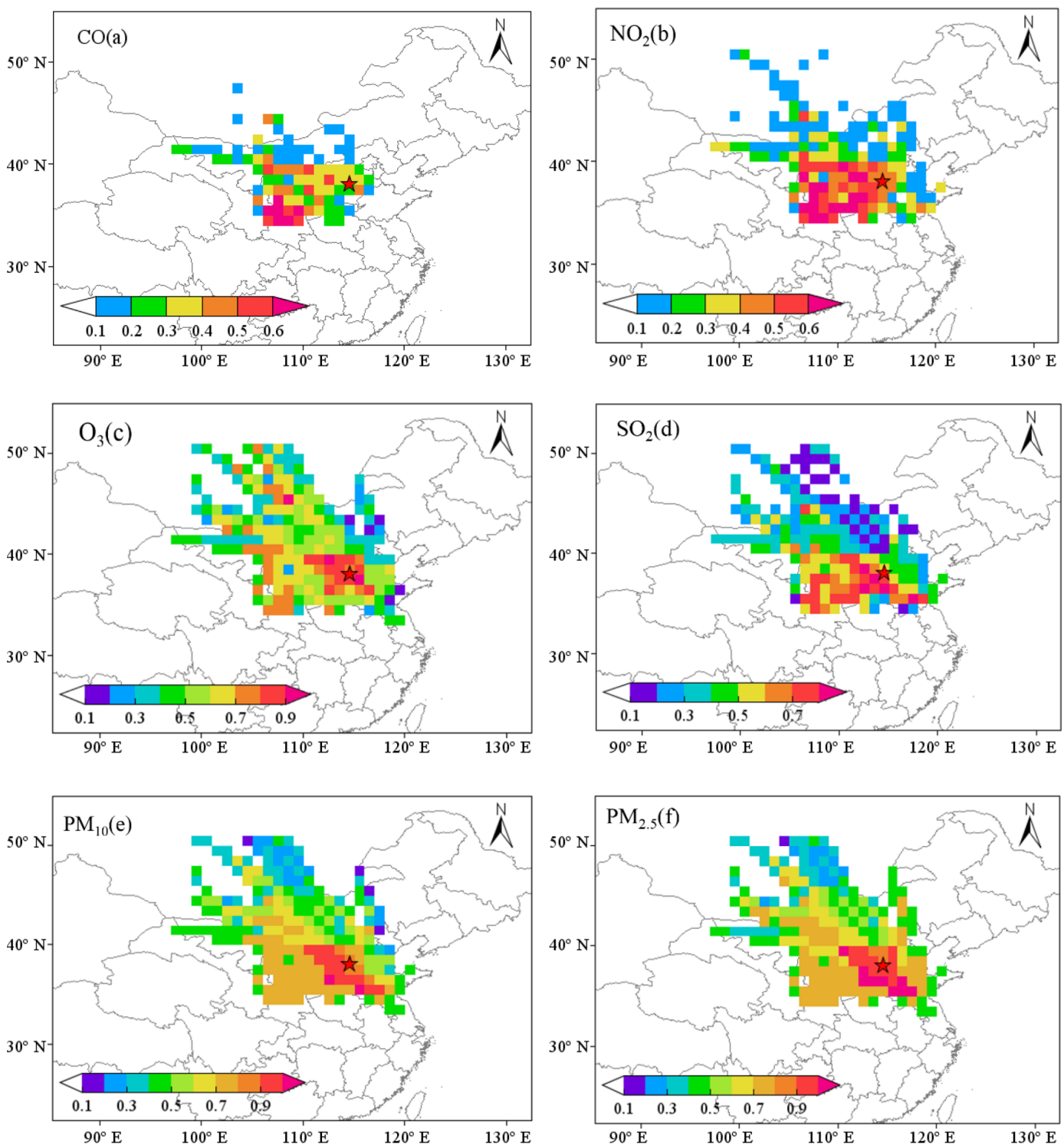

Figure 12. Potential source areas of atmospheric pollutants obtained from the PSCF model during the CAHP. The red star represents Shijiazhuang City. The colours represent potential source areas influencing the atmospheric pollutants; the red colour is relatively important source areas (the values of WPSCF are higher) while the blue colour means unimportant potential source areas (the values of WPSCF are lower). 
especially for the effects of control measures for particulate matter sources. The effects of control measures for $\mathrm{CO}$ emission sources were not apparent during the CAHP, especially in suburbs.

The pollutant emission sources during the CAHP were in effective control, especially for crustal dust and vehicles, while the necessary coal heating for winter and the unfavourable meteorological conditions had an offset effect on the control measures for emission sources to some extent. The discharge of pollutants might still be enormous even under such strict control measures.

The backward trajectory and PSCF analysis in the light of atmospheric pollutants suggested that the potential source areas were mainly concentrated in surrounding regions of Shijiazhuang, i.e. south of Hebei and north of Henan and Shanxi. The regional nature of the atmospheric pollution in the North China Plain revealed that there is an urgent need for making cross-boundary control policy in addition to local control measures given the high background level of pollutants.

The TECA is an important practical exercise but it cannot be advocated as the normalized control measures for atmospheric pollution in China. The direct cause of atmospheric pollution in China is the fact that emission of pollutants exceeds the air environment's self-purification capacity and is caused by an unreasonable and unhealthy pattern for economic development in China.

Data availability. We declare that the underlying research data that can be accessed are in the article and Supplement, but other underlying research data, because we have not been authorized by the relevant cooperation units, cannot be accessed. The data sets are deposited in Nankai University and the Shijiazhuang Environmental Monitoring Center of Hebei Province. When authorized, underlying research data can be obtained from Nankai University and the Shijiazhuang Environmental Monitoring Center of Hebei Province.

\section{The Supplement related to this article is available online} at https://doi.org/10.5194/acp-18-7019-2018-supplement.

Competing interests. The authors declare that they have no conflict of interest.

Acknowledgements. This study was financially supported by the National Key Research and Development Program of China (2016YFC0208500 \& 2016YFC0208501), Tianjin Science and Technology Foundation (16YFZCSF00260), the National Natural Science Foundation of China (21407081), and the Fundamental Research Funds for the Central Universities. The authors thank the Shijiazhuang Environmental Monitoring Center of Hebei Province for their participation in the sampling campaign and chemical analysis of samples.
Edited by: Qiang Zhang

Reviewed by: three anonymous referees

\section{References}

Almeida, S. M., Lage, J., Fernández, B., Garcia, S., Reis, M. A., and Chaves, P. C.: Chemical characterization of atmospheric particles and source apportionment in the vicinity of a steelmaking industry, Sci. Total Environ., 521-522, 411-420, https://doi.org/10.1016/j.scitotenv.2015.03.112, 2015.

Ancelet, T., Davy, P. K., Mitchell, T., Trompette, W. J., Markwitz, A., and Weatherburn, D. C.: Identification of particulate matter sources on an hourly time-scale in a wood burning community, Environ. Sci. Technol., 46, 4767-4774, https://doi.org/10.1021/es203937y, 2012.

Begum, B. A., Kim, E., Biswas, S. K., and Hopke, P. K.: Investigation of sources of atmospheric aerosol at urban and semiurban areas in Bangladesh, Atmos. Environ., 38, 3025-3038, https://doi.org/10.1016/j.atmosenv.2004.02.042, 2004.

Bi, J. R., Huang, J. P., Hu, Z. Y., Holben, B. N., and Guo, Z. Q.: Investigating the aerosol optical and radiative characteristics of heavy haze episodes in Beijing during January of 2013, J. Geophys. Res.-Atmos., 119, 9884-9900, https://doi.org/10.1002/2014JD021757, 2014.

Brown, S. G., Eberly, S., Paatero, P., and Norris, G. A.: Methods for estimating uncertainty in PMF solutions: examples with ambient air and water quality data and guidance on reporting PMF results, Sci. Total Environ., 518-519, 626-635, https://doi.org/10.1016/j.scitotenv.2015.01.022, 2015.

Canha, N., Freitas, M. C., Almeida-Silva, M., Almeida, S. M., Dung, H. M., Dionísio, I., Cardoso, J., Pio, C. A., Caseiro, A., Verburg, T. G., and Wolterbeek, H. T.: Burn wood influence on outdoor air quality in a small village: Foros de Arrão, Portugal, J. Radioanal. Nucl. Ch., 291, 83-88, https://doi.org/10.1007/s10967-011-1261-1, 2012.

Cao, J. J., Chow, J. C., Tao, J., Lee, S. C., Watson, J. G., Ho, K. F., Wang, G. H., Zhu, C. S., and Han, Y. M.: Stable carbon isotopes in aerosols from Chinese cities: influence of fossil fuels, Atmos. Environ., 45, 1359-1363, https://doi.org/10.1016/j.atmosenv.2010.10.056, 2011.

Chen, H. and Wang, H.: Haze Days in North China and the associated atmospheric circulations based on daily visibility data from 1960 to 2012, J. Geophys. Res.-Atmos., 120, 5895-5909, https://doi.org/10.1002/2015JD023225, 2015.

Chen, P. L., Wang, T.J., Lu, X.B., Yu, Y.Y., Kasoar, M., Xie, M., and Zhuang, B.L.: Source apportionment of size-fractionated particles during the 2013 Asian Youth Games and the 2014 Youth Olympic Games in Nanjing, China, Sci. Total Environ., 579, 860-870, https://doi.org/10.1016/j.scitotenv.2016.11.014, 2016.

Chen, R., Zhao, Z., and Kan, H.: Heavy smog and hospital visits in Beijing, China, Am. J. Respi. Crit. Care, 188, 1170-1171, https://doi.org/10.1164/rccm.201304-0678LE, 2013.

Chen, X., Balasubramanian, R., Zhu, Q. Y., Behera, S. N., Bo, D. D., Huang, X., Xie, H. Y., and Cheng, J. P.: Characteristics of atmospheric particulate mercury in size-fractionated particles during haze days in Shanghai, Atmos. Environ., 131, 400-408, https://doi.org/10.1016/j.atmosenv.2016.02.019, 2016. 
Cheng, Y., He, K. B., Du, Z. Y., Zheng, M., Duan, F. K., and Ma, Y. L.: Humidity plays an important role in the $\mathrm{PM}_{2.5}$ pollution in Beijing, Environ. Pollut., 197, 68-75, https://doi.org/10.1016/j.envpol.2014.11.028, 2015.

Dimitriou, K., Remoundaki, E., Mantas, E., and Kassomenos, P.: Spatial distribution of source areas of $\mathrm{PM}_{2.5}$ by Concentration Weighted Trajectory (CWT) model applied in $\mathrm{PM}_{2.5}$ concentration and composition data, Atmos. Environ., 116, 138-145, https://doi.org/10.1016/j.atmosenv.2015.06.021, 2015.

Du, W. P., Wang, Y. S., Song, T., Xin, J. Y., Cheng, Y. S., and Ji, D. S.: Characteristics of atmospheric pollutants during the period of summer and autumn in Shijiazhuang, Environ. Sci., 31, 14091416, 2010 (in Chinese).

Feng, J. L., Yu, H., Su, X. F., Liu, S. H., Li, Y., Pan, Y. P., and Sun, J. H.: Chemical composition and source apportionment of $\mathrm{PM}_{2.5}$ during Chinese Spring Festival at Xinxiang, a heavily polluted city in North China: fireworks and health risks, Atmos. Res., 182, 176-188, https://doi.org/10.1016/j.atmosres.2016.07.028, 2016.

$\mathrm{Fu}, \mathrm{H}$. B. and Chen, J. M.: Formation, features and controlling strategies of severe haze-fog pollutions in China, Sci. Total Environ., 578, 121-138, https://doi.org/10.1016/j.scitotenv.2016.10.201, 2017.

Fu, G. Q., Xu, W. Y., Yang, R. F., Li, J. B., and Zhao, C. S.: The distribution and trends of fog and haze in the North China Plain over the past 30 years, Atmos. Chem. Phys., 14, 11949-11958, https://doi.org/10.5194/acp-14-11949-2014, 2014.

Gao, J., Peng, X., Chen, G., Xu, J., Shi, G. L., Zhang, Y. C., and Feng, Y. C.: Insights into the chemical characterization and sources of $\mathrm{PM}_{2.5}$ in Beijing at a 1h time resolution, Sci. Total Environ., 542, 162-171, https://doi.org/10.1016/j.scitotenv.2015.10.082, 2016.

Gao, M., Guttikunda, S. K., Carmichael, G. R., Wang, Y., Liu, Z., Stanier, C. O., Saide, P. E., and Yu, M.: Health impacts and economic losses assessment of the 2013 severe haze event in Beijing area, Sci. Total Environ., 511, 553-561, https://doi.org/10.1016/j.scitotenv.2015.01.005, 2015.

Gao, X. M., Yang, L. X., Cheng, S. H., Gao, R., Zhou, Y., Xue, L. K., Shou, Y. P., Wang, J., Wang, X. F., Nie, W., Xu, P. J., and Wang, W. X.: Semi-continuous measurement of watersoluble ions in $\mathrm{PM}_{2.5}$ in Jinan, China: Temporal variations and source apportionments, Atmos. Environ., 45, 6048-6056, https://doi.org/10.1016/j.atmosenv.2011.07.041, 2011.

Gu, J. X., Bai, Z. P., Li, A. X., Wu, L. P., Xie, Y. Y., Lei, W. F., Dong, H. Y., and Zhang, X.: Chemical composition of $\mathrm{PM}_{2.5}$ during winter in Tianjin, China, Particuology, 9, 215-221, https://doi.org/10.1016/j.partic.2011.03.001, 2011.

Guo, S., Hu, M., Guo, Q., Zhang, X., Schauer, J. J., and Zhang, R.: Quantitative evaluation of emission controls on primary and secondary organic aerosol sources during Beijing 2008 Olympics, Atmos. Chem. Phys., 13, 8303-8314, https://doi.org/10.5194/acp-13-8303-2013, 2013.

Han, S. Q., Wu, J. H., Zhang, Y. F., Cai, Z. Y., Feng, Y. C., Yao, Q., Li, X. J., Liu, Y. W., and Zhang, M.: Characteristics and formation mechanism of a winter haze-fog episode in Tianjin, China, Atmos. Environ., 98, 323-330, https://doi.org/10.1016/j.atmosenv.2014.08.078, 2014.

Hao, T. Y., Han, S. Q., Chen, S. C., Shan, X. L., Zai, Z. Y., Qiu, X. B., Yao, Q., Liu, J. L., Chen, J., and Meng. L. H.: The role of fog in haze episode in Tianjin, China: A case study for November 2015, Atmos. Res., 194. 235-244, https://doi.org/10.1016/j.atmosres.2017.04.020, 2017.

Jiang, B. F. and Xia, D. H.: Role identification of $\mathrm{NH}_{3}$ in atmospheric secondary new particle formation in haze occurrence of China, Atmos. Environ., 163, 107-117, https://doi.org/10.1016/j.atmosenv.2017.05.035, 2017.

Kabala, C. and Singh, B. R.: Fractionation and mobility of copper, lead, and zinc in soil profiles in the vicinity of a copper smelter, J. Environ. Qual., 30, 485-492, https://doi.org/10.2134/jeq2001.302485x, 2001.

Kong, X. Z., He, W., Qin, N., He, Q. S., Yang, B., Ouyang, H. L., Wang, Q. M., and Xu, F. L.: Comparison of transport pathways and potential sources of $\mathrm{PM}_{10}$, in two cities around a large Chinese lake using the modified trajectory analysis, Atmos. Res., 122, 284-297, https://doi.org/10.1016/j.atmosres.2012.10.012, 2013.

Lee, H., Honda, Y., Hashizume, M., Guo, Y. L., Wu, C. F., Kan, H., Jung, K., Lim, Y. H., Yi, S., and Kim, H.: Short-term exposure to fine and coarse particles and mortality: a multicity time-series study in East Asia, Environ. Pollut., 207, 43-51, https://doi.org/10.1016/j.envpol.2015.08.036, 2015.

Li, H. M., Wang, Q. G., Shao, M., Wang, J. H., Wang, C., Sun, Y. X., Qian, X., Wu, H. F., Yang, M., and Li, F. Y.: Fractionation of airborne particulate bound elements in haze-fog episode and associated health risks in a megacity of southeast China, Environ. Pollut., 208, 655-662, https://doi.org/10.1016/j.envpol.2015.10.042, 2016.

Li, J. J., Wang, G. H., Ren, Y. Q., Wang, J. Y., Wu, C., Han, Y. N., Zhang, L., Cheng, C. L., and Meng, J. J.: Identification of chemical compositions and sources of atmospheric aerosols in Xi'an, inland China during two types of haze events, Sci. Total Environ., 566-567, 230-237, https://doi.org/10.1016/j.scitotenv.2016.05.057, 2016.

Li, M., Tang, G. Q., Huang, J., Liu, A. R., An, J. L., and Wang, Y. S.: Characteristics of winter atmospheric mixing layer height in Beijing-Tianjin-Hebei region and their relationship with the atmospheric pollution, Environ. Sci., 36, 1935-1943, 2015 (in Chinese).

Lin, Y.-C., Tsai, C.-J., Wu, Y.-C., Zhang, R., Chi, K.-H., Huang, Y.-T., Lin, S.-H., and Hsu, S.-C.: Characteristics of trace metals in traffic-derived particles in Hsuehshan Tunnel, Taiwan: size distribution, potential source, and fingerprinting metal ratio, Atmos. Chem. Phys., 15, 4117-4130, https://doi.org/10.5194/acp15-4117-2015, 2015.

Liu, B. S., Song, N., Dai, Q. L., Mei, R. B., Sui, B. H., Bi, X. H., and Feng, Y. C.: Chemical composition and source apportionment of ambient $\mathrm{PM}_{2.5}$ during the nonheating period in Taian, China, Atmos. Res., 170, 23-33, https://doi.org/10.1016/j.atmosres.2015.11.002, 2016.

Liu, B. S., Wu, J. H., Zhang, J. Y., Wang, L., Yang, J. M., Liang, D. N., Dai, Q. L., Bi, X. H., Feng, Y. C., Zhang, Y. F., and Zhang, Q.X.: Characterization and source apportionment of $\mathrm{PM}_{2.5}$ based on error estimation from EPA PMF 5.0 model at a medium city in China, Environ. Pollut., 222, 10-22, https://doi.org/10.1016/j.envpol.2017.01.005, 2017a.

Liu, B. S., Yang, J. M., Yuan, J., Wang, J., Dai, Q. L., Li, T. K., Bi, X. H., Feng, Y. C., Xiao, Z. M., Zhang, Y. F., and $\mathrm{Xu}, \mathrm{H}$.: Source apportionment of atmospheric pollutants based on the online data by using PMF and ME2 
models at a megacity, China, Atmos. Res., 185, 22-31, https://doi.org/10.1016/j.atmosres.2016.10.023, 2017b.

Liu, B. S., Li, T. K., Yang, J. M., Wu, J. H., Gao, J. X., Bi, X. H., Feng, Y. C., Zhang, Y. F., and Yang, H. H.: Source apportionment and a novel approach of estimating regional contributions to ambient $\mathrm{PM}_{2.5}$ in Haikou, China, Environ. Pollut., 223, 334-345, https://doi.org/10.1016/j.envpol.2017.01.030, 2017c.

Liu, G., Li, J. H., Wu, D., and $\mathrm{Xu}, \mathrm{H}$. : Chemical composition and source apportionment of the ambient $\mathrm{PM}_{2.5}$ in Hangzhou, China, Particuology, 18, 135-143, https://doi.org/10.1016/j.partic.2014.03.011, 2015.

Liu, H., Wang, X. M., Zhang, J. P., He, K. B., Wu, Y., and $\mathrm{Xu}$, J. Y.: Emission controls and changes in air quality in Guangzhou during the Asian Games, Atmos. Environ., 76, 8193, https://doi.org/10.1016/j.atmosenv.2012.08.004, 2013.

Ma, Z. Z., Li, Z., Jiang, J. K., Ye, Z. X., Deng, J. G., and Duan, L.: Characteristics of water-soluble inorganic ions in $\mathrm{PM}_{2.5}$ emitted from coal fired power plants, Environ. Sci., 36, 2361-2366, 2015 (in Chinese).

Mansha, M., Ghauri, B., Rahman, S., and Amman, A.: Characterization and source apportionment of ambient air particulate matter $\left(\mathrm{PM}_{2.5}\right)$ in Karachi, Sci. Total Environ., 425, 176-183, https://doi.org/10.1016/j.scitotenv.2011.10.056, 2012.

Meng, C. C., Wang, L. T., Zhang, F. F., Wei, Z., Ma, S. M., Ma, X., and Yang, J.: Characteristics of concentrations and water-soluble inorganic ions in $\mathrm{PM}_{2.5}$ in Handan City, Hebei province, China, Atmos. Res., 171, 133-146, https://doi.org/10.1016/j.atmosres.2015.12.013, 2016.

Morishita, M., Gerald, J., Keeler, G. J., Kamal, A. S., Wagner, J. G., Harkema, J. R., and Rohr, A. C.: Source identification of ambient $\mathrm{PM}_{2.5}$ for inhalation exposure studies in Steubenville, Ohio using highly time-resolved measurements, Atmos. Environ., 45, 7688-7697, https://doi.org/10.1016/j.atmosenv.2010.12.032, 2011.

Paatero, P.: User's Guide for Positive Matrix Factorization Programs PMF2 and PMF3, Part 1: Tutorial, University of Helsinki, Helsinki, Finland (February), 2000.

Paatero, P. and Hopke, P. K.: Discarding or down-weighting highnoise variables in factor analytic models, Anal. Chim. Acta, 490, 277-289, https://doi.org/10.1016/S0003-2670(02)01643-4, 2003.

Paatero, P. and Tapper, U.: Positive matrix factorization: a non-negative factor model with optimal utilization of error estimates of data values, Environmetrics, 5, 111-126, https://doi.org/10.1002/env.3170050203, 1994.

Pan, Q., Yu, Y., Tang, Z., Xi, M., and Zang, G.: Haze, a hotbed of respiratory-associated infectious diseases, and a new challenge for disease control and prevention in China, Am. J. Infect. Control, 42, p. 688, https://doi.org/10.1016/j.ajic.2014.03.001, 2014.

Peng, W., Yang, J. N., Wagner, F., and Mauzerall, D. L.: Substantial air quality and climate co-benefits achievable now with sectoral mitigation strategies in China, Sci. Total Environ., 598, 10761084, https://doi.org/10.1016/j.scitotenv.2017.03.287, 2017.

Qin, K., Wu, L. X., Wong, M. S., Letu, H., Hu, M. Y., Lang, H. M., Sheng, S. J., Teng, J. Y., Xiao, X., and Yuan, L. M.: Trans-boundary aerosol transport during a winter haze episode in China revealed by ground-based Lidar and CALIPSO satellite, Atmos. Environ., 141, 20-29, https://doi.org/10.1016/j.atmosenv.2016.06.042, 2016.
Quinn, P. K., and Bates, T. S.: North American, Asian, and Indian haze: similar regional impacts on climate? Geophys. Res. Lett., 30, 193-228, https://doi.org/10.1029/2003GL016934, 2003.

Santacatalina, M., Reche, C., Minguillón, M. C., Escrig, A., Sanfelix, V., Carratalá, A., Nicolás, J. F., Yubero, E., Crespo, J., Alastuey, A., Monfort, E., Miró, J. V., and Querol, X.: Impact of fugitive emissions in ambient PM levels and composition: A case study in Southeast Spain, Sci. Total Environ., 408, 49995009, https://doi.org/10.1016/j.scitotenv.2010.07.040, 2010.

Shafer, M. M., Toner, B. M., Overdier, J. T., Schauer, J. J., Fakra, S. C., Hu, S., Herner, J. D., and Ayala, A.: Chemical speciation of vanadium in particulate matter emitted from diesel vehicles and urban atmospheric aerosols, Environ. Sci. Technol., 46, 189-195, https://doi.org/10.1021/es200463c, 2012.

Shen, X. J., Sun, J. Y., Zhang, X. Y., Zhang, Y. M., Zhang, L., Che, H. C., Ma, Q. L., Yu, X. M., Yue, Y., and Zhang, Y. W.: Characterization of submicron aerosols and effect on visibility during a severe haze-fog episode in Yangtze River Delta, China, Atmos. Environ., 120, 307-316, https://doi.org/10.1016/j.atmosenv.2015.09.011, 2015.

Shen, Z. X., Cao, J., Arimoto, R., Han, Y. M., Zhu, C.S., Tian, J., and Liu, S. X.: Chemical characteristics of fine particles $\left(\mathrm{PM}_{1}\right)$ from Xi'an, China, Aerosol Sci. Technol., 44, 461-472, https://doi.org/10.1080/02786821003738908, 2010.

Srimuruganandam, B., and Nagendra, S. M. S.: Application of positive matrix factorization in characterization of $\mathrm{PM}_{10}$ and $\mathrm{PM}_{2.5}$ emission sources at urban roadside, Chemosphere, 88, 120-130, https://doi.org/10.1016/j.chemosphere.2012.02.083, 2012.

Sun, X., Yin, Y., Sun, Y. W., Sun, Y., Liu, W., and Han, Y.: Seasonal and vertical variations in aerosol distribution over Shijiazhuang, China, Atmos. Environ., 81, 245-252, https://doi.org/10.1016/j.atmosenv.2013.08.009, 2013.

Sun, Y. L., Wang, Z. F., Wild, O., Xu, W. Q., Chen, C., Fu, P. Q., Du, W., Zhou, L. B., Zhang, Q., Han, T. T., Wang, Q. Q., Pan, X. L., Zheng, H. T., Li, J., Guo, X. F., Liu, J. G., and Worsnop, D. R.: "APEC Blue": Secondary Aerosol Reductions from Emission Controls in Beijing, Sci. Rep., 6, 20668, https://doi.org/10.1038/srep20668, 2016.

Tai, A. P. K., Mickley, L. J., and Jacob, D. J.: Correlations between fine particulate matter $\left(\mathrm{PM}_{2.5}\right)$ and meteorological variables in the United States: implications for the sensitivity of $\mathrm{PM}_{2.5}$ to climate change, Atmos. Environ., 44, 3976-3984, https://doi.org/10.1016/j.atmosenv.2010.06.060, 2010.

Tao, J., Zhang, L., Engling, G., Zhang, R., Yang, Y., Cao, J. J., Zhu, C. S., Wang, Q. Y., and Luo, L.: Chemical composition of $\mathrm{PM}_{2.5}$ in an urban environment in Chengdu, China: importance of springtime dust storms and biomass burning, Atmos. Res., 122, 270-283, https://doi.org/10.1016/j.atmosres.2012.11.004, 2013a.

Tao, J., Cheng, T. T., Zhang, R. J., Cao, J. J., Zhu, L. H., Wang, Q. Y., Luo, L., and Zhang, L. M.: Chemical Composition of $\mathrm{PM}_{2.5}$ at an Urban Site of Chengdu in Southwestern China, Adv. Atmos. Sci., 30, 1070-1084, 2013b.

Tao, M., Chen, L., Xiong, X., Zhang, M., Ma, P., Tao, J., and Wang, Z.: Formation process of the widespread extreme haze pollution over northern China in January 2013: Implications for regional air quality and climate, Atmos. Environ., 98, 417-425, https://doi.org/10.1016/j.atmosenv.2014.09.026, 2014. 
UNEP (United Nations Environmental Programme): Independent Environmental Assessment Beijing 2008 Olympic Games, Nairobi, Kenya, 2009, available at: https://www.unenvironment.org/resources/report/ (last access: 23 September 2017), 2010.

Wang, G., Zhang, R., Gomez, M. E., Yang, L., Levy Zamora, M., Hu, M., Lin, Y., Peng, J., Guo, S., Meng, J., Li, J., Cheng, C., Hu, T., Ren, Y., Wang, Y., Gao, J., Cao, J., An, Z., Zhou, W., Li, G., Wang, J., Tian, P., Marrero-Ortiz, W., Secrest, J., Du, Z., Zheng, J., Shang, D., Zeng, L., Shao, M., Wang, W., Huang, Y., Wang, Y., Zhu, Y., Li, Y., Hu, J., Pan, B., Cai, L., Cheng, Y., Ji, Y., Zhang, F., Rosenfeld, D., Liss, P. S., Duce, R. A., Kolb, C. E., and Molina, M. J.: Persistent sulfate formation from London Fog to Chinese haze, P. Natl. Acad. Sci. USA., 113, 13630-13635, https://doi.org/10.1073/pnas.1616540113, 2016.

Wang, G., Cheng, S. Y., Wei, W., Yang, X. W., Wang, X. Q. Jia, J., Lang, J. L., and Lv, Z.: Characteristics and emissionreduction measures evaluation of $\mathrm{PM}_{2.5}$ during the two major events: APEC and Parade, Sci. Total Environ., 595, 81-92, https://doi.org/10.1016/j.scitotenv.2017.03.231, 2017.

Wang, H. B., Zhao, L. J., Xie, Y. J., and Hu, Q. M.: "APEC blue" - The effects and implications of joint pollution prevention and control program, Sci. Total Environ., 553, 429-438, https://doi.org/10.1016/j.scitotenv.2016.02.122, 2016.

Wang, H. L., Qiao, L. P., Lou, S. R., Zhou, M., Ding, A. J., Huang, H. Y., Chen, J. M., Wang, Q., Tao, S. K., Chen, C. H., Li, L., and Huang, C.: Chemical composition of $\mathrm{PM}_{2.5}$ and meteorological impact among three years in urban Shanghai, China, J. Clean. Prod., 112, 1302-1311, https://doi.org/10.1016/j.jclepro.2015.04.099, 2016.

Wang, L. T., Wei, Z., Yang, J., Zhang, Y., Zhang, F. F., Su, J., Meng, C. C., and Zhang, Q.: The 2013 severe haze over southern Hebei, China: model evaluation, source apportionment, and policy implications, Atmos. Chem. Phys., 14, 3151-3173, https://doi.org/10.5194/acp-14-3151-2014, 2014.

Wang, M., Zhu, T., Zheng, J., Zhang, R. Y., Zhang, S. Q., Xie, X. X., Han, Y. Q., and Li, Y.: Use of a mobile laboratory to evaluate changes in on-road air pollutants during the Beijing 2008 Summer Olympics, Atmos. Chem. Phys., 9, 8247-8263, https://doi.org/10.5194/acp-9-8247-2009, 2009.

Wang, P., Cao, J. J., Shen, Z. X., Han, Y. M., Lee, S. C., Huang, Y., Zhu, C. S., Wang, Q. Y., Xu, H. M., and Huang, R. J.: Spatial and seasonal variations of $\mathrm{PM}_{2.5}$ mass and species during 2010 in Xi'an, China, Sci. Total Environ., 508, 477-487, https://doi.org/10.1016/j.scitotenv.2014.11.007, 2015.

Wang, Q. Z., Zhuang, G. S., Huang, K., Liu, T. N., Deng, C. R., Xu, J., Lin, Y. F., Guo, Z. G., Chen, Y., Fu, Q. Y., and Fu, J. S.: Probing the severe haze pollution in three typical regions of China: Characteristics, sources and regional impacts, Atmos. Environ., 120, 76-88, https://doi.org/10.1016/j.atmosenv.2015.08.076, 2015.

Wang, T., Nie, W., Gao, J., Xue, L. K., Gao, X. M., Wang, X. F., Qiu, J., Poon, C. N., Meinardi, S., Blake, D., Wang, S. L., Ding, A. J., Chai, F. H., Zhang, Q. Z., and Wang, W. X.: Air quality during the 2008 Beijing Olympics: secondary pollutants and regional impact, Atmos. Chem. Phys., 10, 7603-7615, https://doi.org/10.5194/acp-10-7603-2010, 2010.

Wang, Y. Q., Zhang, X. Y., and Draxler, R.: TrajStat: GIS-based software that uses various trajectory statistical analysis meth- ods to identify potential sources from long-term air pollution measurement data, Environ. Modell. Softw., 24, 938-939, https://doi.org/10.1016/j.envsoft.2009.01.004, 2009.

Wu, D., Liao, G. L., Deng, X. J., Bi, X. Y., Tan, H. B., Li, F., Jiang, C. L., Xia, D., and Fan, S. J.: Transport condition of surface layer under haze weather over the Pearl River Delta, Acta. Meteorol. Sin., 68, 680-688, 2008 (in Chinese).

Wu, H., Zhang, Y. F., Han, S. Q., Wu, J. H., Bi, X. H., Shi, G. L., Wang, J., Yao, Q., Cai, Z. Y., Liu, J. L., and Feng, Y. C.: Vertical characteristics of $\mathrm{PM}_{2.5}$ during the heating season in Tianjin, China, Sci. Total Environ., 523, 152-160, https://doi.org/10.1016/j.scitotenv.2015.03.119, 2015.

Yang, H. N., Chen, J., Wen, J. J., Tian, H. Z., and Liu, X. G.: Composition and sources of $\mathrm{PM}_{2.5}$ around the heating periods of 2013 and 2014 in Beijing: Implications for efficient mitigation measures, Atmos. Environ., 124, 378-386, https://doi.org/10.1016/j.atmosenv.2015.05.015, 2016.

Yang, L. L., Feng, Y., Jin, W., Li, Y. Q., Zhou, J. B., Jiang, J. B., and Li, Z. G.: Pollution characteristic of water soluble inorganic ion in atmospheric particles in Shijiazhuang, Adm. Tech. Environ. Monit., 26, 17-21, 2016 (in Chinese).

Yang, Y., Liu, X. G., Qu, Y., Wang, J. L., An, J. L., Zhang, Y. H. G., and Zhang, F.: Formation mechanism of continuous extreme haze episodes in the megacity Beijing, China, in January 2013, Atmos. Res., 155, 192-203, https://doi.org/10.1016/j.atmosres.2014.11.023, 2015.

Yao, L., Yang, L. X., Yuan, Q., Yan, C., Dong, C., Meng, C. P., Sui, X., Yang, F., Lu, Y. L., and Wang, W. X.: Sources apportionment of $\mathrm{PM}_{2.5}$ in a background site in the North China Plain, Sci. Total Environ., 541, 590-598, https://doi.org/10.1016/j.scitotenv.2015.09.123, 2016.

Zhang, J. K., Sun, Y., Liu, Z. R., Ji, D. S., Hu, B., Liu, Q., and Wang, Y. S.: Characterization of submicron aerosols during a month of serious pollution in Beijing, 2013, Atmos. Chem. Phys., 14, 2887-2903, https://doi.org/10.5194/acp-14-2887-2014, 2014.

Zhang, L., Wang, T., Lv, M. Y., and Zhang, Q.: On the severe haze in Beijing during January 2013: unraveling the effects of meteorological anomalies with WRF-Chem, Atmos. Environ., 104, 11-21, https://doi.org/10.1016/j.atmosenv.2015.01.001, 2015.

Zhang, Q. H., Zhang, J. P., and Xue, H. W.: The challenge of improving visibility in Beijing, Atmos. Chem. Phys., 10, 78217827, https://doi.org/10.5194/acp-10-7821-2010, 2010.

Zhang, T., Cao, J. J., Tie, X. X., Shen, Z. X., Liu, S. X., Ding, H., Han, Y. M., Wang, G. H., Ho, K. F., Qiang, J., and Li, W. T.: Water-soluble ions in atmospheric aerosols measured in Xi' an, China: seasonal variations and sources, Atmos. Res., 102, 110 119, https://doi.org/10.1016/j.atmosres.2011.06.014, 2011.

Zhang, X. Y., Wang, L., Wang, W. H., Cao, D. J., and Ye, D .X.: Long-term trend and spatiotemporal variations of haze over China by satellite observations from 1979 to 2013, Atmos. Environ., 119, 362-373, https://doi.org/10.1016/j.atmosenv.2015.08.053, 2015.

Zhang, Z. L., Wang, J., Chen, L. H., Chen, X. Y., Sun, G. Y., Zhong, N. S., Kan, H. D., and Lu, W. J.: Impact of haze and air pollution-related hazards on hospital admissions in Guangzhou, China, Environ. Sci. Pollut. R., 21, 4236-4244, https://doi.org/10.1007/s11356-013-2374-6, 2014.

Zhao, B., Wang, P., Ma, J. Z., Zhu, S., Pozzer, A., and Li, W.: A high-resolution emission inventory of primary pollutants for 
the Huabei region, China, Atmos. Chem. Phys., 12, 481-501, https://doi.org/10.5194/acp-12-481-2012, 2012.

Zhao, P. S., Zhang, X. L., and Xu, X. F.: Long-term visibility trends and characteristics in the region of Beijing, Tianjin, and Hebei, China, Atmos. Res., 101, 711-718, https://doi.org/10.1016/j.atmosres.2011.04.019, 2011.

Zhou, M. G., He, G. J., Fan, M. Y., Wang, Z. X., Liu, Y., Ma, J., Ma, Z. W., Liu, J. M., Liu, Y. N., and Wang, L. D.: Smog episodes, fine particulate pollution and mortality in China, Environ. Res., 136, 396-404, https://doi.org/10.1016/j.envres.2014.09.038, 2015.
Zhu, L., Huang, X., Shi, H., Cai, X. H., and Song, Y.: Transport pathways and potential sources of $\mathrm{PM}_{10}$ in Beijing, Atmos. Environ., 45, 594-604, https://doi.org/10.1016/j.atmosenv.2010.10.040, 2011. 